\title{
„Fabryka” pałacu w Wilanowie za czasów Elżbiety Sieniawskiej. Uwagi na temat organizacji magnackiego placu budowy w XVIII w.
}

$\mathrm{D}$ nia 29 lipca 1720 r. Elżbieta z Lubomirskich Sieniawska (1669-1729) nabyła za niebagatelną kwotę 400 tysięcy tynfów (432 tysięcy zł) dobra wilanowskie (il. 1). Zakup podwarszawskiej rezydencji Jana III przez hetmanową wielką koronną i kasztelanową krakowską był zwieńczeniem nie tylko długotrwałych targów z Augustem $\mathrm{II}^{1}$, lecz także sukcesywnego skupowania dóbr królewskich². Jak powszechnie wiadomo, pałac wilanowski, podobnie jak cały tamtejszy klucz dóbr, był w momencie zakupu przez Sieniawską w opłakanym stanie. Już w momencie starania się o Wilanów wyceniła ona koszt remontu samego pałacu na kwotę 30 tysięcy tynfów ${ }^{3}$. Znana z umiejętności organizacyjnych

\footnotetext{
${ }^{1}$ Piotr BOHDZIEWICZ, „Wilanów za Sieniawskiej”, Biuletyn Historii Sztuki, R. XVII: 1955, nr 3, s. 373-374; id., Korespondencja artystyczna Elżbiety Sieniawskiej z lat 1700-1729 w zbiorach Czartoryskich w Krakowie, Lublin 1964, s. 164-165 (Towarzystwo Naukowe katolickiego Uniwersytetu Lubelskiego. Rozprawy Wydziału Historyczno-Filologicznego, t. 30). Kwestię targów o Wilanów szczegółowo przedstawia Janusz NOWAK, „Dobra wilanowskie za Elżbiety Sieniawskiej 1720-1729 w świetle archiwaliów Biblioteki Czartoryskich w Krakowie”, Studia Wilanowskie, 2003, t. 14, s. 54-56; Rafał NESTOROW, „Between art and politics. Wilanów in the times of Elżbieta Sieniawska neé Lubomirska (1720-1729)", [w:] The Baroque villa. Suburban and Country Residences c. 1600-1800, red. Barbara ARCISZEWSKA, Wilanów 2009, s. 155-166; id., „Spazzio (Spazio, Spacy, Spatz) Giovanni (Jan)”, [w:] Słownik architektów i budowniczych środowiska warszawskiego XV-XVIII wieku, red. Paweł MIGASIEWICZ, Hanna OSIECKA-SAMSONOWICZ, Jakub SITO, Warszawa 2016, s. 444-449; id., „Tajemnicze okoliczności śmierci Giovanniego Spazzia, nadwornego architekta Elżbiety z Lubomirskich Sieniawskiej. Przyczynek do biografii”, Biuletyn Historii Sztuki, R. LXXVIII: 2016, nr 3, s. 505-512; id., Pro domo et nomine suo. Fundacje i inicjatywy artystyczne Adama Mikołaja i Elżbiety Sieniawskich, Warszawa 2016, s. 53-54, 307-330. Zob. też: Barbara SMOLEŃSKA, „Z dziejów dóbr wilanowskich w XVI-XVIII wieku”, Rocznik Warszawski, R. XV: 1979, s. 289-320.

2 Krzysztof KOSSARZECKI, „Podziały dóbr Sobieskich w latach 1698-1699”, Studia Wilanowskie, 2004, t. 14, s. 525. Zob. też: Marek KOMASZYŃSKI, Maria Kazimiera D’Arquien Sobieska, królowa Polski 1641-1716, Kraków 1983, s. 230-231; Andrzej K. LINK-LENCZOWSKI, „Sieniawscy i Sobiescy po śmierci Jana III”, Acta Universitatis Wratislaviensis, 1984, nr 726: Historia 47, s. 250-256; Bożena POPIOŁEK, Królowa bez korony. Studium z życia i działalności Elżbiety z Lubomirskich Sieniawskiej, ok. 1669-1729, Kraków 1996, s. 36-37, 42-43, 54, 78, 85, 102-106; Andrzej K. LINK-LENCZOWSKI, Bożena POPIOŁEK, „Sieniawska z Lubomirskich Elżbieta Helena (1669-1729)”, [w:] Polski Stownik Biograficzny, t. 37, Warszawa 1996, s. 90-91, 95; Agnieszka SŁABY, Rzadziocha oleszycka. Dwór Elżbiety z Lubomirskich Sieniawskiej jako przykład patronatu kobiecego w czasach saskich, Kraków 2014, s. 31-32; NESTOROW, Pro domo et nomine suo..., s. 54, 307, 400.

${ }^{3}$ Biblioteka Jagiellońska (BJ), rkps 1152, E. Sieniawska do J. Sobieskiego, 13 III 1720; BOHDZIEWICZ, „Korespondencja artystyczna...", s. 57.
} 


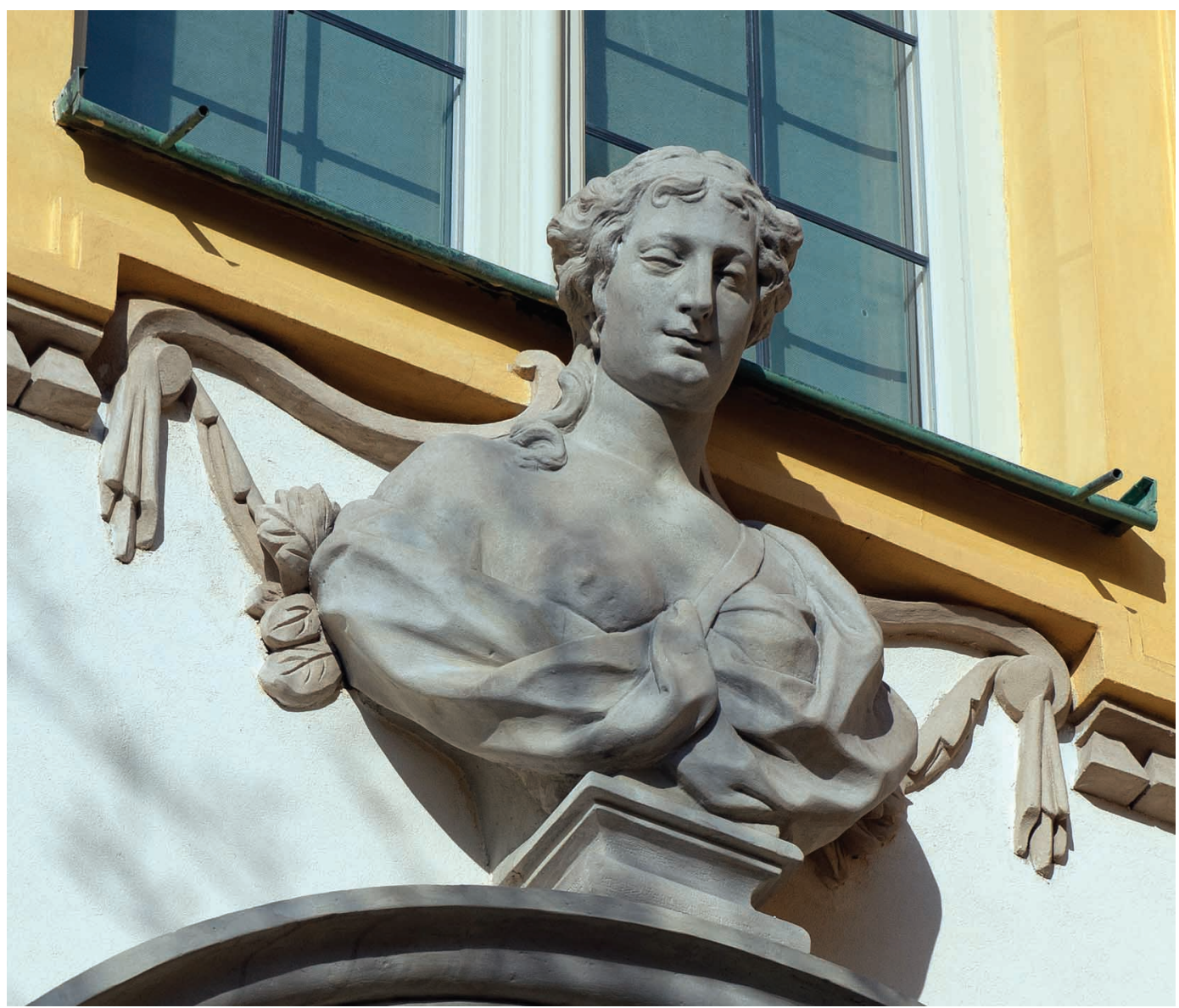

1. Johann Georg Plersch, popiersie kobiece (Elżbieta z Lubomirskich Sieniawska?) na elewacji od strony dziedzińca pałacu w Wilanowie, 1725. Fot. Rafat Nestorow

hetmanowa przystąpiła niemal natychmiast do prac, kierując do Wilanowa lustratorów w celu oszacowania wydatków i możliwości przywrócenia płynności finansowej tamtejszemu majątkowi, równocześnie szykując się do kosztownego remontu królewskiego pa$\mathrm{łacu}^{4}$.

Omawiając prace prowadzone przy rezydencji wilanowskiej z inicjatywy Elżbiety Sieniawskiej należy zwrócić uwagę na stosunkowo niewielki udział artystów z jej stałego warsztatu. Zasadniczy człon zespołu był bardzo nieliczny i opierał się na wykonawcach sprowadzanych okresowo przez hetmanową z Łubnic (Giovanni Spazzio, Francesco Fumo, Pietro Innocente Comparetti) oraz sezonowo przywożonych z dóbr ruskich cieśli, kowali, szklarzy i innych pomniejszych rzemieślników. Liczba prowadzonych przez hetmanową przedsięwzięć artystycznych w interesującym nas okresie była olbrzymia, co zmuszało jej stały warsztat artystyczny do ciagłej mobilności. Nie pozwalało to na ściągnieęcie wszystkich artystów do prac przy wilanowskim pałacu (il. 2) $)^{5}$. W związku z tym

\footnotetext{
${ }^{4}$ NOWAK, „Dobra wilanowskie...”, s. 57-62; NESTOROW, „Spazzio (Spazio, Spacy, Spatz) Giovanni...”, s. 447; id., Pro domo et nomine suo..., s. 54, 61-62, 136.

${ }^{5} \mathrm{Na}$ temat organizacji prac artystycznych na dworze hetmanowej oraz zatrudnianych przez nią artystach ostatnio najwięcej informacji podał NESTOROW, Pro domo et nomine suo..., s. 93-146. Zob. też: Jacek GAJEWSKI, „Elżbieta Sieniawska i jej artyści. Z zagadnień organizacji pracy artystycznej i odbioru w XVIII wieku w Polsce”, [w:] Mecenas, kolekcjoner, odbiorca. Materiały z Sesji SHS. Katowice listopad 1981, Warszawa 1984, s. 281-302; id., „Architekci w służbie i na usługach hetmanowej Elżbiety Sieniawskiej”, [w:] Podług nieba i zwyczaju polskiego. Studia z historii
} 


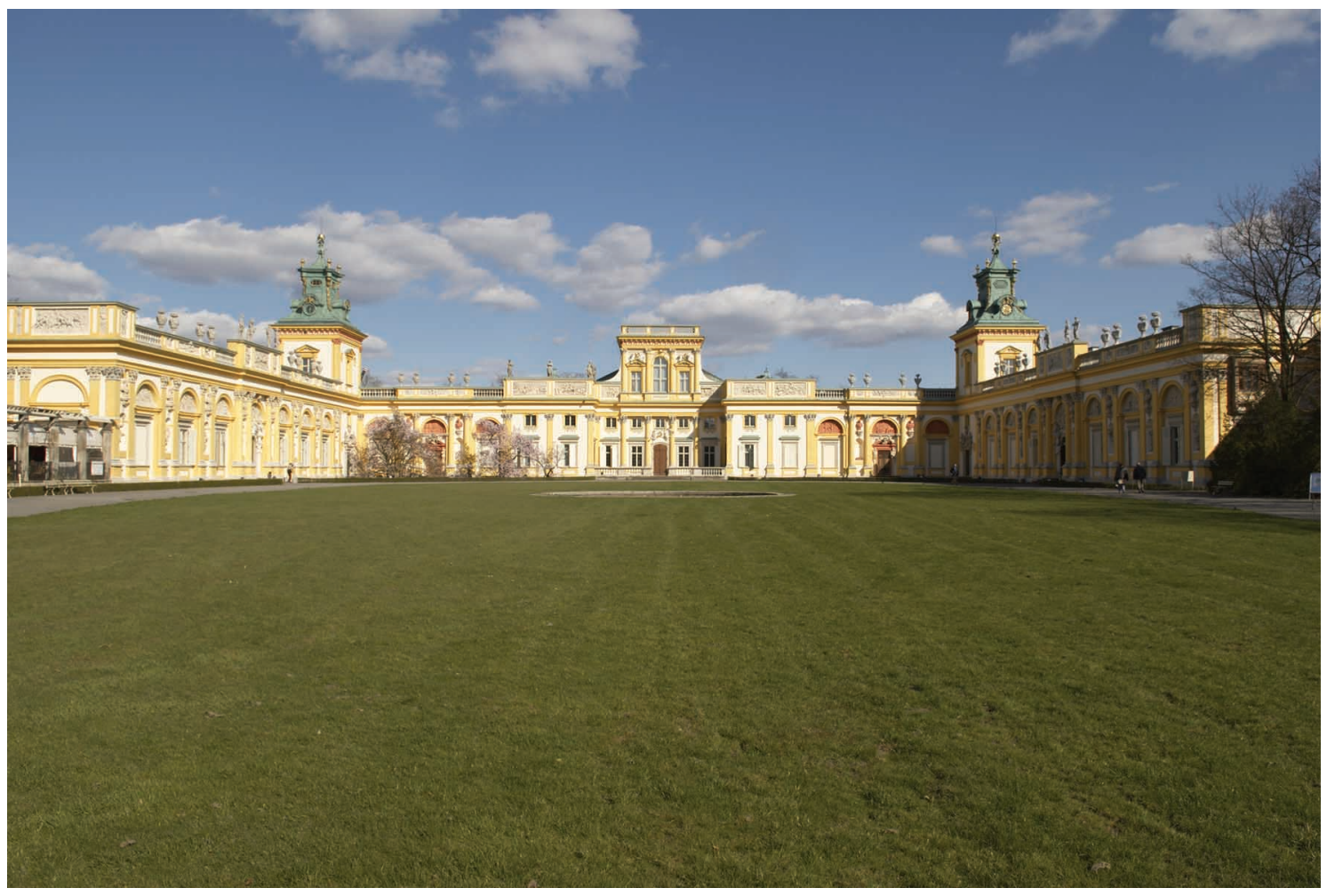

2. Pałac w Wilanowie, widok od strony dziedzińca. Fot. Piotr Jamski

Sieniawska była zmuszona zdać się na usługi artystów miejscowych ${ }^{6}$. Niezwykle znamienne dla dalszego przebiegu prac było zatrudnienie już w roku 1720 za 2 tysiące talarów Giuseppe Fontany, który miał dokonać oględzin budowli i przygotować wstępny kosztorys najpilniejszych prac zabezpieczających, a więc przede wszystkim naprawy cieknących dachów oraz przeszklenia wybitych okien ${ }^{7}$. Praca tego warszawskiego architekta nie ograniczyła się wyłącznie do określenia zakresu i przygotowania kosztorysu prac, ale przede wszystkim do zapewnienia materiałów budowlanych i siły roboczej, którą Fontana jako prężny przedsiębiorca budowlany dysponował. Przypuszczać można, że w zatrudnieniu pomogły mu kontakty wujów - architektów Domenica i Giovanniego Battisty Ceronich, którzy byli zatrudniani przez Sieniawską. Fontanę łączyły również bliskie związki

\footnotetext{
architektury, sztuki i kultury polskiej ofiarowane Adamowi Miłobędzkiemu, Warszawa 1988, s. 377-390; Rafał NESTOROW, „Sieniawscy w Warszawie czasów Augusta II. Kilka uwag o wzajemnych relacjach artystycznych”, [w:] Kultura artystyczna Warszawy XVII-XXI w., red. Zbigniew MICHALCZYK, Andrzej PIEŃKOS, Michał WARDZYŃSKI, Warszawa 2010, s. 145-157; id., „Artyści i rzemieślnicy z krajów Monarchii Habsburskiej w służbie Elżbiety z Lubomirskich Sieniawskiej”, [w:] Między Wrocławiem a Lwowem. Sztuka na Ślasku, w Małopolsce i na Rusi Koronnej od XVI do XVIII wieku. Materiały z ogólnopolskiej konferencji naukowej, red. Andrzej BETLEJ, Katarzyna BRZEZINA, Piotr OSZCZANOWSKI, Wrocław-Kraków 2011, s. 279-291; Rafał NESTOROW, Jakub SITO, Rezydencja $i$ dobra wilanowskie w XVIII wieku w świetle archiwaliów z Biblioteki Czartoryskich, Wilanów 2010; id., „Stolarz czy architekt? Przypadek Konrada Kotschenreitera”, [w:] Między Wrocławiem a Lwowem..., s. 291-304; NESTOROW, „Spazzio (Spazio, Spacy, Spatz) Giovanni...”, s. 444-449.

${ }^{6}$ NESTOROW, „Sieniawscy w Warszawie...”, s. 152-153; id., Pro domo et nomine suo ..., s. 116-129.

${ }^{7}$ Biblioteka Czartoryskich w Krakowie (BCzart.), rkps 5953, 1. 39821, G. Spazzio do E. Sieniawskiej, 4 VIII 1720; BCzart., rkps 5809, 1. 10701, G. Fontana do E. Sieniawskiej, 22 VIII 1720. BOHDZIEWICZ, „Korespondencja artystyczna...”, s. 58; NESTOROW, „Sieniawscy w Warszawie...”, s. 152-153; NESTOROW, SITO, Rezydencja i dobra wilanowskie...; NESTOROW, Pro domo et nomine suo ..., s. 7-12, 119-120; Monika WYSZOMIRSKA, „Fontana (Fontanna, Fontani) Giuseppe Giacomo (Józef)”, [w:] Słownik architektów i budowniczych środowiska warszawskiego..., s. $132-133$.
} 


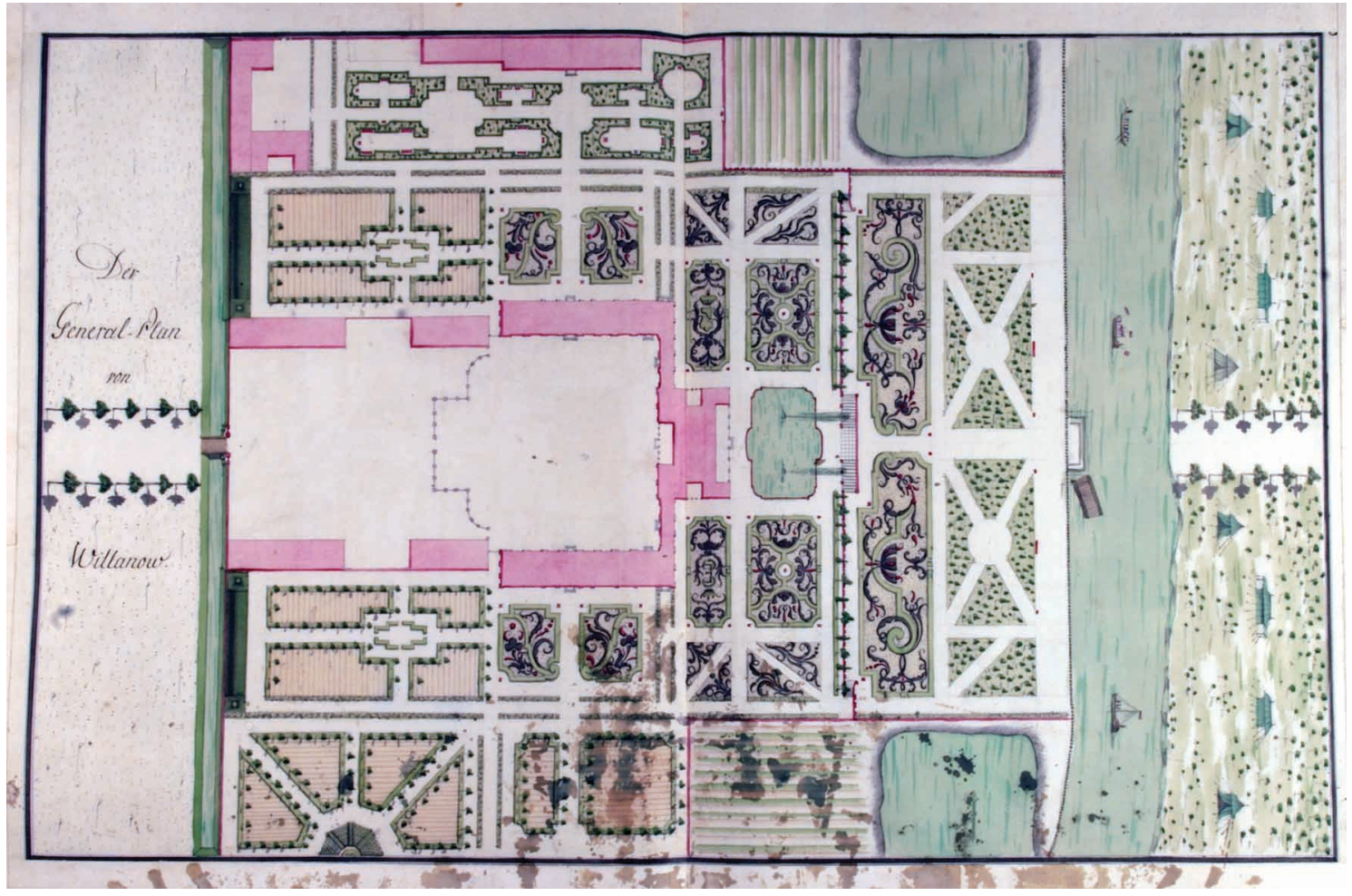

3. Plan założenia pałacowo-ogrodowego w Wilanowie z tzw. Albumu Poturzyckiego, ok. 1732, Biblioteka Ukraińskiej Akademii Nauk im. W. Stefanyka we Lwowie. Fot. Piotr Jamski

z rodziną Solarich, a zwłaszcza z królewskim kamieniarzem Rocco (opiekował się jego dziećmi), który również pracował dla hetmanowej ${ }^{8}$. Przede wszystkim zaś Giuseppe Fontana zatrudniony był od roku 1717 przez Sieniawskich przy budowie pałacu hetmana Adama Mikołaja na Krakowskim Przedmieściu ${ }^{9}$. Kontakty Fontany w środowisku warszawskim pozwoliły Sieniawskiej nie tylko zwerbować całą rzesze bezimiennych kamieniarzy, murarzy i innych rzemieślników, ale zapewne też malarza Giuseppe Rossiego, pozostającego, jak można przypuszczać, w kręgu mecenatu królewskiego. Być może kontaktom Fontany hetmanowa zawdzięczała usługi Johanna Georga Plerscha ${ }^{10}$. Artystów warszawskich najmował również sam Spazzio, często odwiedzając stolicę, m.in. w celu znalezienia malarza do pozłoty bani, blacharza królewskiego, rzeźbiarza czy sztukatora.

\footnotetext{
${ }^{8}$ NESTOROW, „Sieniawscy w Warszawie...”, s. 146-155; id., Pro domo et nomine suo..., s. 97, 117, 119; WYSZOMIRSKA, „Fontana (Fontanna, Fontani) Giuseppe...”, s. 131-132. Zob. też: Piotr ŁUGOWSKI, „Solari (Solary, Solario) Rocco (właśc. Giovanni Battista Rocco), [w:] Stownik architektów i budowniczych środowiska warszawskiego..., s. $441-443$

${ }^{9}$ Rafał NESTOROW, „Jan Baptysta Dessieur - architekt, inżynier czy plenipotent Adama Mikołaja Sieniawskiego?”, Biuletyn Historii Sztuki, R. 71: 2009, nr 3, s. 346; id., „Sieniawscy w Warszawie...”, s. 149-150; id., Pro domo et nomine suo..., s. 68, 71-75. Ostatnio na temat Ceronich zob. Piotr ŁUGOWSKI, „Ceroni (Cyroni, Zeroni) Domenico“, [w:] Stownik architektów i budowniczych środowiska warszawskiego..., s. 91-92; id., „Ceroni (Cyroni, Zeroni) Francesco", [w:] ibid., s. 92-94.

${ }^{10}$ NESTOROW, „Sieniawscy w Warszawie...”, s. 153; id., „Wilanowski epizod Johanna Georga Plerscha w świetle nieznanych materiałów archiwalnych”, Studia Wilanowskie, 2011, t. 18, s. 62-75; Jakub SITO, „Debiut Johanna Georga Plerscha w «fabryce» pałacowej w Wilanowie”, Studia Wilanowskie, 2011, t. 18, s. 76-84; id., Wielkie warsztaty rzeźbiarskie warszawy doby saskiej. Modele kariery - formacja artystyczna - organizacja produkcji, Warszawa 2013, s. 159-163; Rafał NESTOROW, „Pies w niedźwiedziej skórze. Raz jeszcze o dekoracji rzeźbiarskiej wilanowskiej bramy głównej”, Roczniki Humanistyczne, 2017, t. LXV, z. 4, s. 35-47.
} 


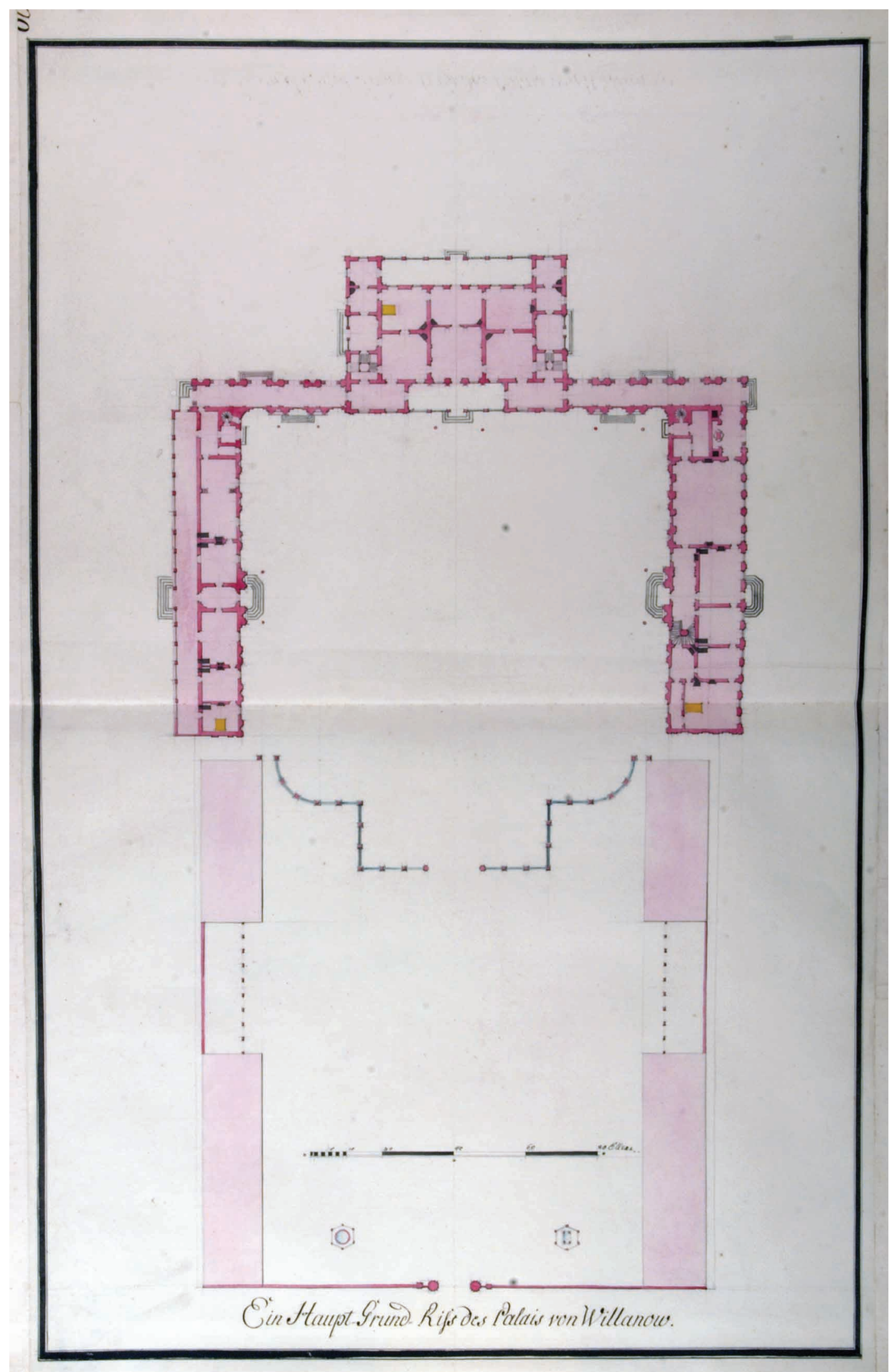

4. Rzut założenia pałacowego w Wilanowie z tzw. Albumu Poturzyckiego, ok. 1732, Biblioteka Ukraińskiej Akademii Nauk im. W. Stefanyka we Lwowie. Fot. Piotr Jamski 


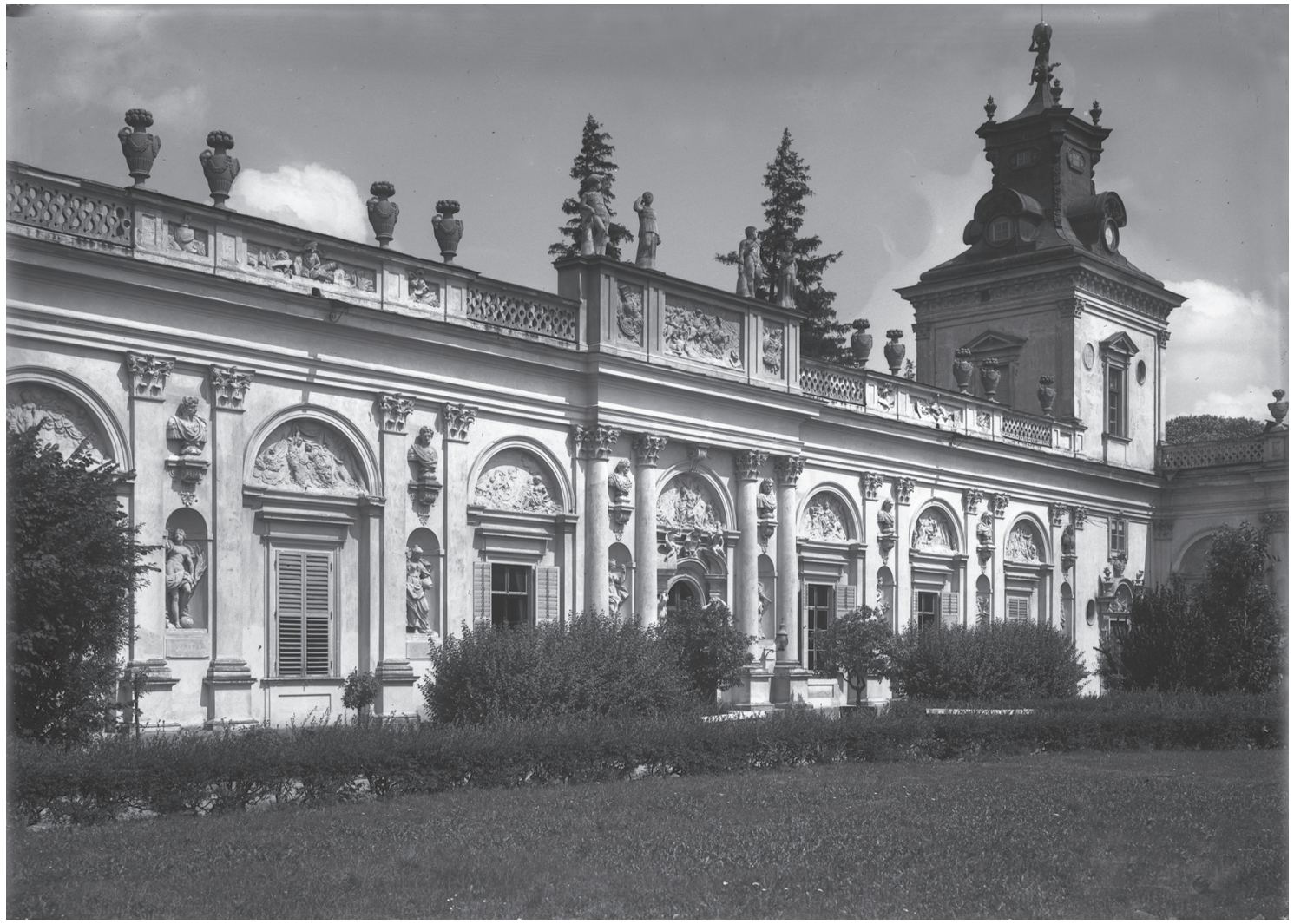

5. Francesco Fumo, Pietro Innocente Comparetti, dekoracja sztukatorska skrzydła pótnocnego pałacu w Wilanowie. Fot. S.N. Nowiński, 1915, IS PAN

W Wilanowie zatrudniony został ponownie Carlo Bay, tym razem po to, by wymurował ogrodowe studnie ${ }^{11}$. Kontakty artystyczne ułatwiały też przyjaźnie pomiędzy artystami. Spazzio pozostawał w zażyłych stosunkach z Giuseppe Fontaną, architekta Sieniawskiej odwiedzali też często pobratymcy, licznych gości przyjmowały żony Francesca Fuma i Giuseppe Rossiego (il. 3-4) ${ }^{12}$.

Prace remontowe przy rezydencji ruszyły niemal natychmiast po zakupie podwarszawskich dóbr przez hetmanową. Już w początku sierpnia 1720 r. Giovanni Spazzio, korzystając z zakończenia pewnego etapu prac przy pałacu w Łubnicach, zalecał wysłać część tamtejszych rzemieślników do Wilanowa. Pomimo zatrudnienia Giuseppe Fontany remontem pałacu kierował przyjeżdżający okresowo do Wilanowa główny architekt hetmanowej Giovanni Spazzio. Niezbędne prace blacharskie miał wykonać anonimowy blacharz królewski, a ostatecznie zadanie to powierzono rzemieślnikowi z tzw. zakrakowskich dóbr hetmanowej - Ferdynandowi Heindlowi, z którym kontrakt podpisał Spazzio w marcu 1722 r. (il. 5) ${ }^{13} \mathrm{~W}$ tym samym czasie rozpoczęto prace przy jednej z wież pałacowych (określanej mianem „,nowej”), która pozostawała wówczas nieukończona (z pewnością nie miała hełmu i zapewne przykryta tymczasowym dachem). Druga z wież, której

\footnotetext{
${ }^{11}$ BOHDZIEWICZ, „Korespondencja artystyczna...”, s. 82; NESTOROW, „Sieniawscy w Warszawie...”, s. 153; Jakub SITO, „BAY (Bai, Baia, Baio, Baya) Carlo Antonio Maria (Karol Antoni), [w:] Słownik architektów i budowniczych środowiska warszawskiego..., s. 38.

12 NESTOROW, „Sieniawscy w Warszawie...”, s. 15; id., Pro domo et nomine suo..., s. 231.

${ }^{13}$ BCzart., rkps 5829, F. Heindl do E. Sieniawskiej, 1. 14243-4261 z lat 1721-1722 (wszystkie opublikowane w: $\mathrm{Ad}$ villam novam. Materiały do dziejów rezydencji, t. 1, oprac. Jakub SITO, red. Magdalena GUTOWSKA, Warszawa 2008, s. 53-64); NESTOROW, Pro domo et nomine suo..., s. 113.
} 


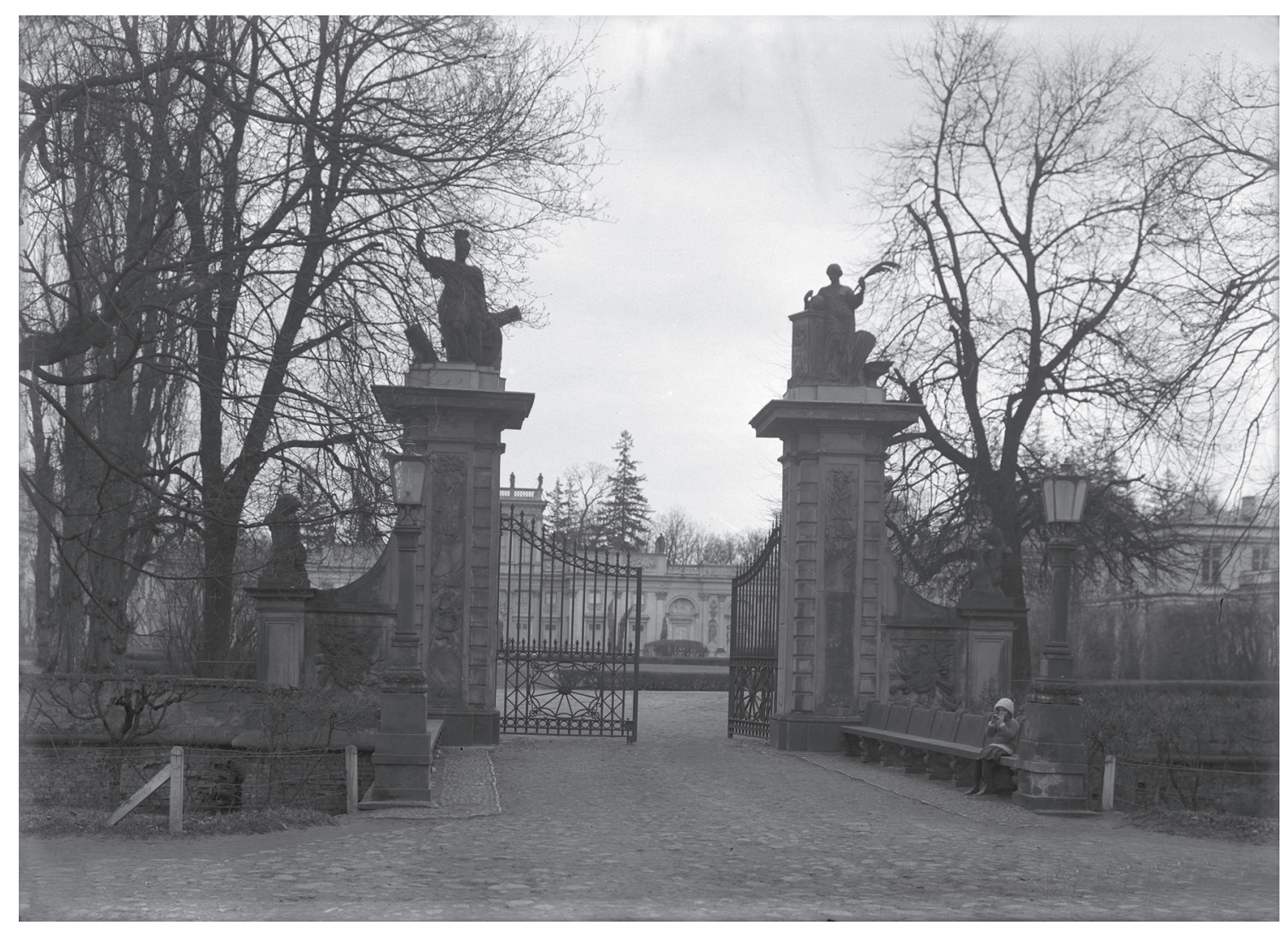

6. Johann Georg Plersch, dekoracja filarów bramy wjazdowej do pałacu w Wilanowie, po 1728. Fotografia z 1915 r., IS PAN

hełm wykonano w ostatnich latach panowania Jana III lub, co bardziej prawdopodobne, już po śmierci monarchy z inicjatywy królewiczów, wymagał całkowitej wymiany. Nowy hełm zaprojektowany najpewniej przez Spazzia zrobił wspomniany krakowski kotlarz Ferdynad Heindl. Do wykonania figury Atlasa Spazzio chciał nająć Bartłomieja Michała Bernatowicza, który przygotował najprawdopodobniej elementy dekoracji wieży (festony, espagnioletty), zaś figurę wyrzeźbił młody Johann Georg Plersch, który w niedługim czasie został zatrudniony w Wilanowie ze stałą pensją (il. 6) ${ }^{14}$. Ostatecznie rzeźbiarz wykonał również Atlasa na drugą z wież, który osadzony został na miejscu pod koniec lipca 1723 r. ${ }^{15}$ Prace sztukatorskie wykonywał początkowo przyjeżdżający z Łubnic Francesco Fumo, od roku 1725 wspomagany przez sprowadzonego z Czech ornamentalistę Pietra Innocente Comparettiego. Obydwaj artyści pracowali zarówno przy dekoracjach wznoszonego północnego skrzydła pałacu, jak również przy niezbędnych pracach naprawczych dekoracji korpusu pałacu (il. 7-8). Prace prowadzone w reprezentacyjno-mieszkalnych pomieszczeniach pałacu w latach 1722-1723 miały w znacznej mierze charakter doraźnych reparacji oraz napraw szkód, jakie powodowały przeciekające dachy oraz rynny, które na bieżąco naprawiał Ferdinand Heindl. Przeciekające pokrycie uszkodziło w dość dużym stopniu dekorację tzw. Sali Uczt Jana III ${ }^{16}$. Niewykluczone, że do prac konserwa-

\footnotetext{
${ }^{14}$ NESTOROW, „Wilanowski epizod...”, s. 64-65; SITO, „Debiut Johanna Georga Plerscha...”, s. 78-80.

15 BCzart., rkps 5953, 1. 39789, G. Spazzio do E. Sieniawskiej (przed 8 VII 1723); BCzart., rkps 5980, P. Więckowski do E. Sieniawskiej, 1. 46881 (22 VII 1723); 1. 46884 (2 IX 1723); 1. 46880 (1 VII 1723). NESTOROW, „Wilanowski epizod...”, s. 65; SITO, „Debiut Johanna Georga Plerscha...”, s. 80.

${ }^{16}$ BCzart., rkps 5980, P. Więckowski do E. Sieniawskiej, 1. 46872 (15 IV 1723); 1. 46878 (20 VI 1723); 1.46881 (22 VII
} 


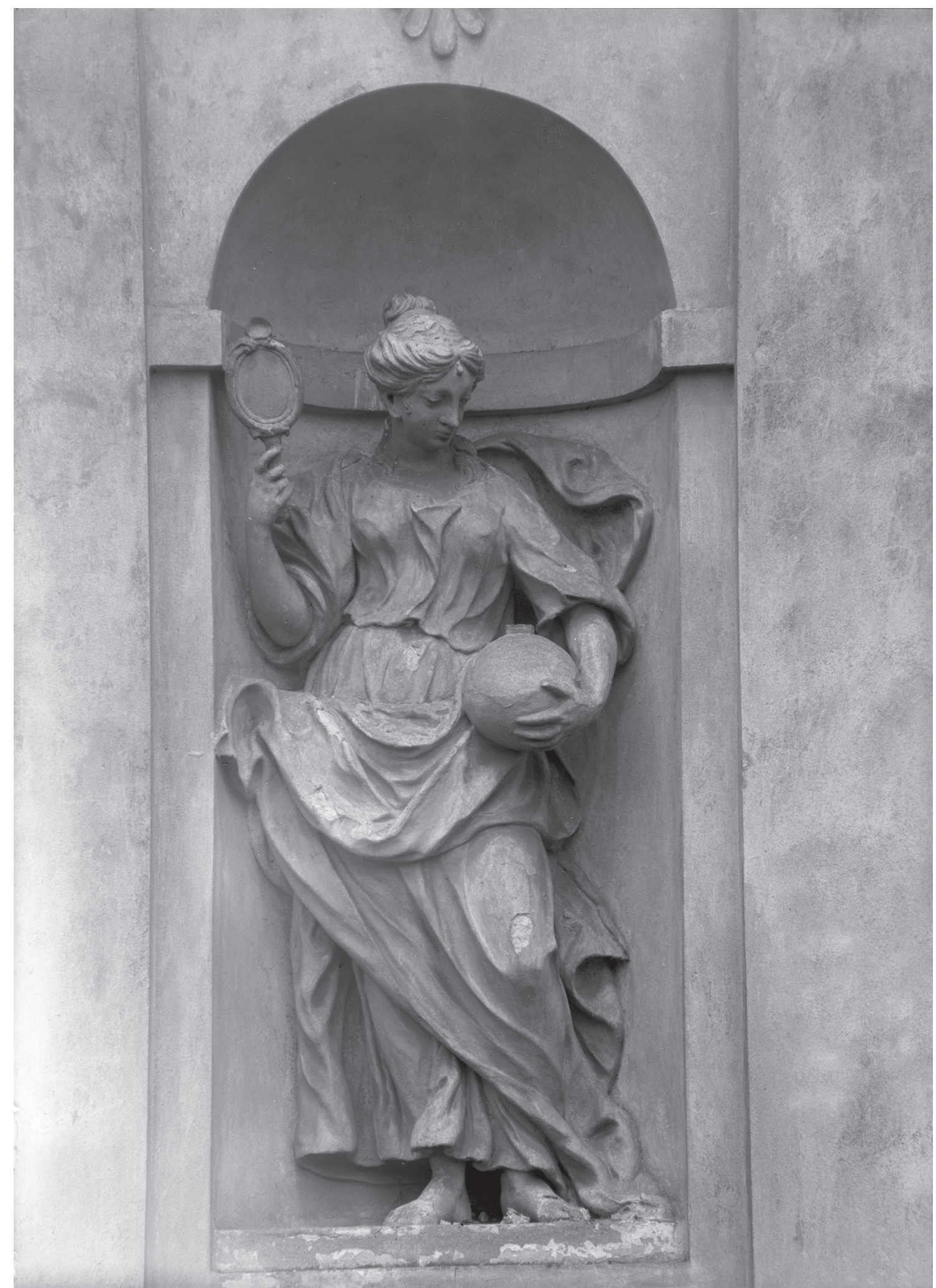

7. Francesco Fumo, personifikacja Wiedzy na elewacji skrzydta pótnocnego pałacu $w$ Wilanowie, po 1723. Fot. F. Jaworski, 1922, IS PAN 


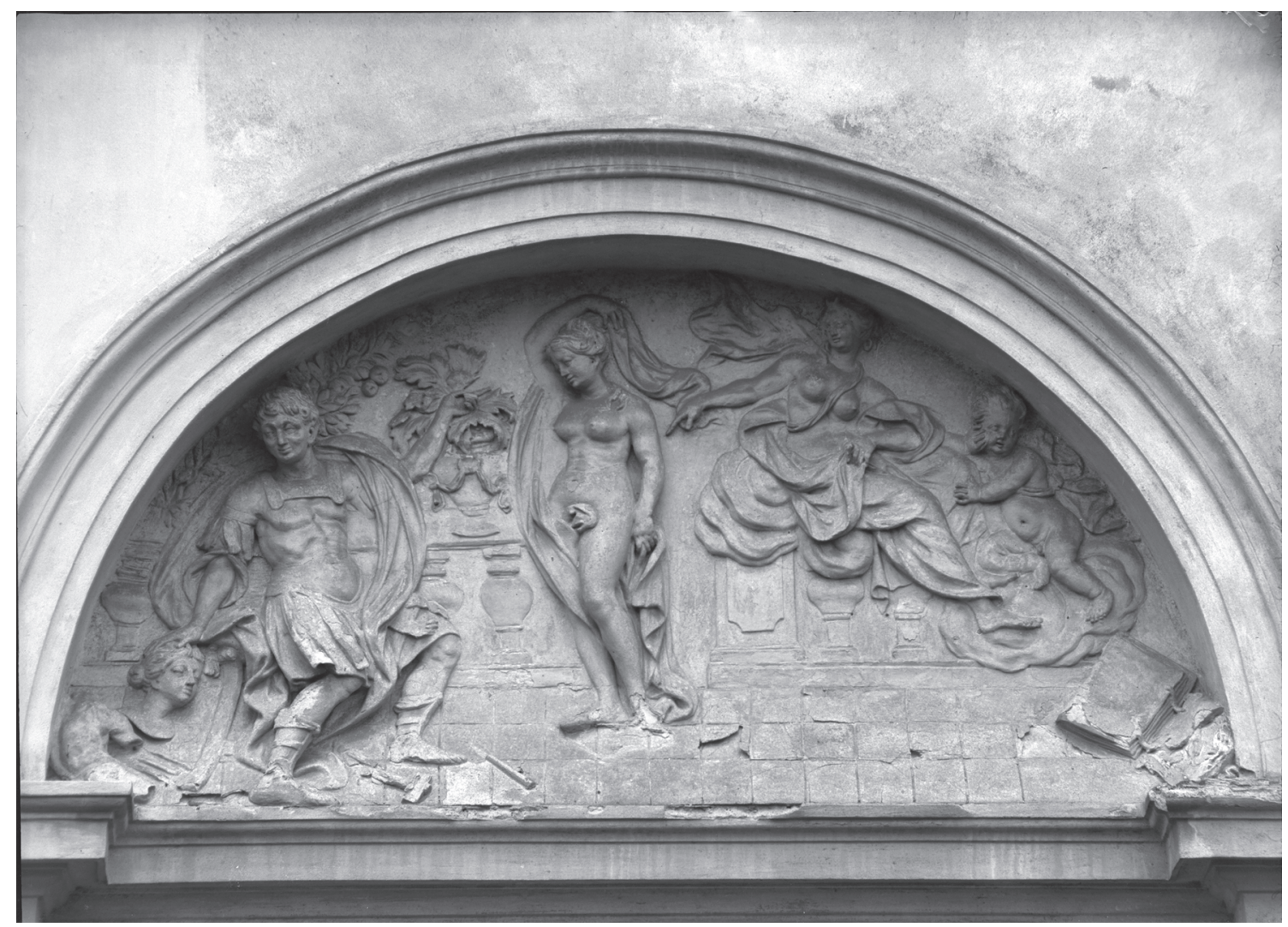

8. Francesco Fumo, Pigmalion i Galatea, płaskorzeźba na elewacji skrzydta pótnocnego pałacu w Wilanowie, po 1723. Fot. F. Jaworski, 1922, IS PAN

torskich przy uszkodzonych malowidłach Sieniawska zatrudniła królewskiego malarza Giuseppe Rossiego, który oprócz napraw w Sali Uczt Jana III (il. 9) czy pałacowych galeriach dekorował wiodące do niej klatki schodowe, a także pokoje i gabinety czy sień nowo wznoszonego skrzydła północnego (il. 10) ${ }^{17}$.

W świetle ujawnionych materiałów archiwalnych pod znakiem zapytania staje przypisywana wcześniej Fontanie funkcja konduktora prowadzącego całość prac budowlanych w Wilanowie. W znacznej mierze sam Spazzio czuwał nad ich przebiegiem, wydając odpowiednie dyspozycje ${ }^{18}$. Co ciekawe, w czasie jego pobytu Fontana mógł opuścić Wilanów, pozostawiając plac budowy pod czujnym okiem nadwornego archi-

1723); 1. 46883 (26 VIII 1723); 1. 46884 (2 IX 1723); 1.46885 (9 IX 1723). Informacje o bieżących remontach również w kilku listach G. Spazzia, opublikowanych przez Bohdziewicza („Korespondencja artystyczna...”, s. 61-64). Zob. też: NESTOROW, Pro domo et nomine suo..., s. 107, 120-121, 132.

${ }^{17}$ BOHDZIEWICZ, „Korespondencja artystyczna...”, s. 38-40, 112-114, 270-273, 316; NESTOROW, „Sieniawscy w Warszawie...”, s. 153; Aleksandra BERNATOWICZ, „Rossi (Rossy, Rosy) Giuseppe”, [w:] Stownik artystów polskich $i$ obcych $w$ Polsce działajacych (zmartych przed 1966 r.): malarze, rzeźbiarze, graficy, t. 9, red. Małgorzata BIERNACKA, Warszawa 2013, s. 123-124; NESTOROW, Pro domo et nomine suo..., s. 120-121. Ostatnio na temat G. Rossiego zob. Rafał NESTOROW, „Dekoracja malarska sklepienia kościoła jezuitów pw. Najświętszej Maryi Panny w Jarosławiu autorstwa Giuseppe Rossiego. Uwagi na marginesie działalności fundatorskiej Elżbiety z Lubomirskich Sieniawskiej", [w:] Bazylika Matki Boskiej Bolesnej w Jarosławiu. Dzieje, ludzie i sztuka, red. Marek MIŁAWICKI OP, Rafał NESTOROW, Kraków 2016, s. 539-552 (Studia i Źródła Dominikańskiego Instytutu Historycznego w Krakowie, red. Tomasz GAŁUSZKA OP, t. 16).

${ }^{18}$ BCzart., rkps 5980, 1. 46884, P. Więckowski do E. Sieniawskiej, 2 IX 1723: Na przeszła niedzielę z rana przyjechat tu sztukator z kwadratorem, któremu dat[em] miejsce w kuchni, a to dla pieca żeby gips który tu jest wypalit sobie dla swojej roboty, potem pan Spazio ma mu ordinować co do niego należy. 


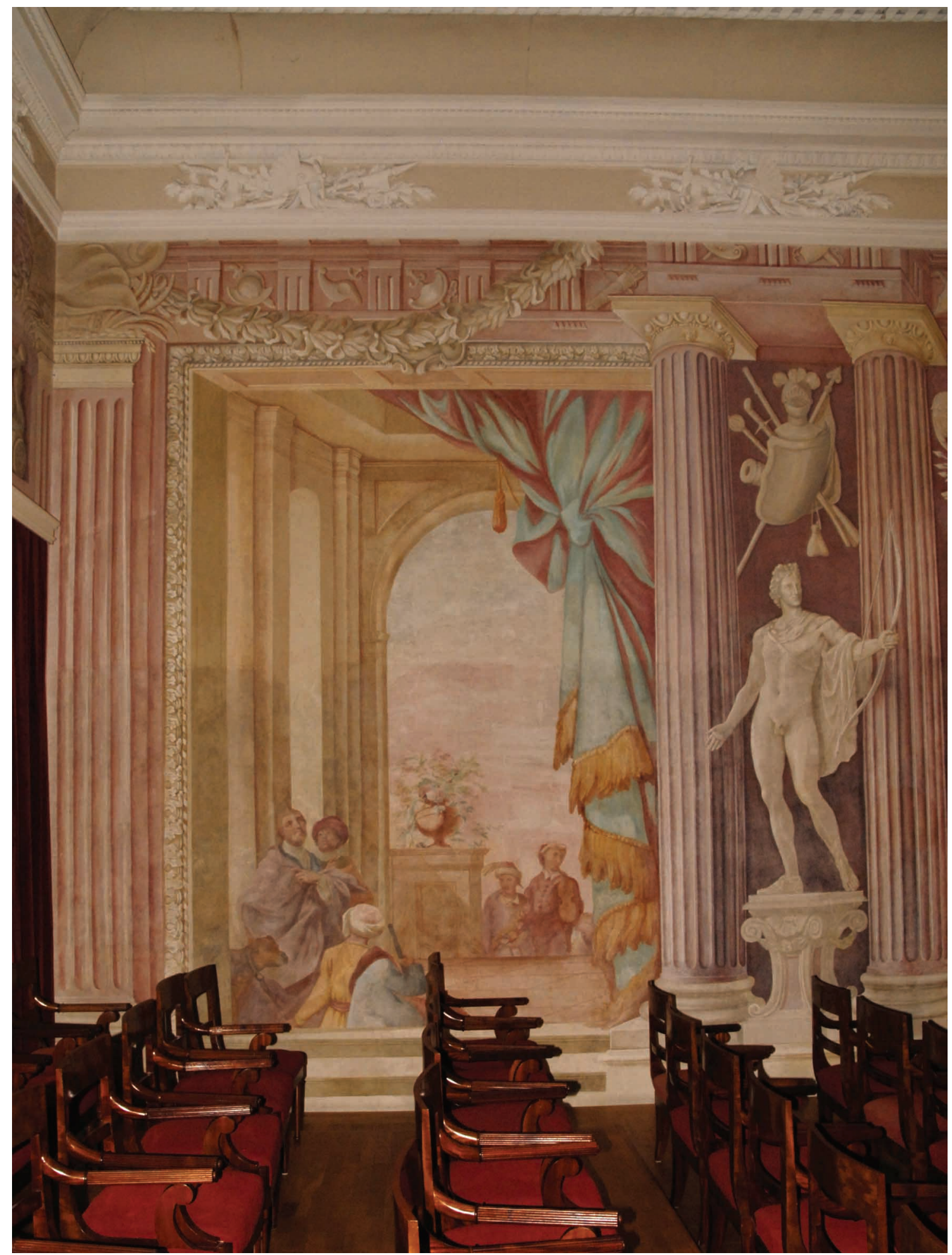

9. Giuseppe Rossi, dekoracja malarska Sali Uczt Jana III w pałacu w Wilanowie, 1724-1725. Fot. Rafat Nestorow 


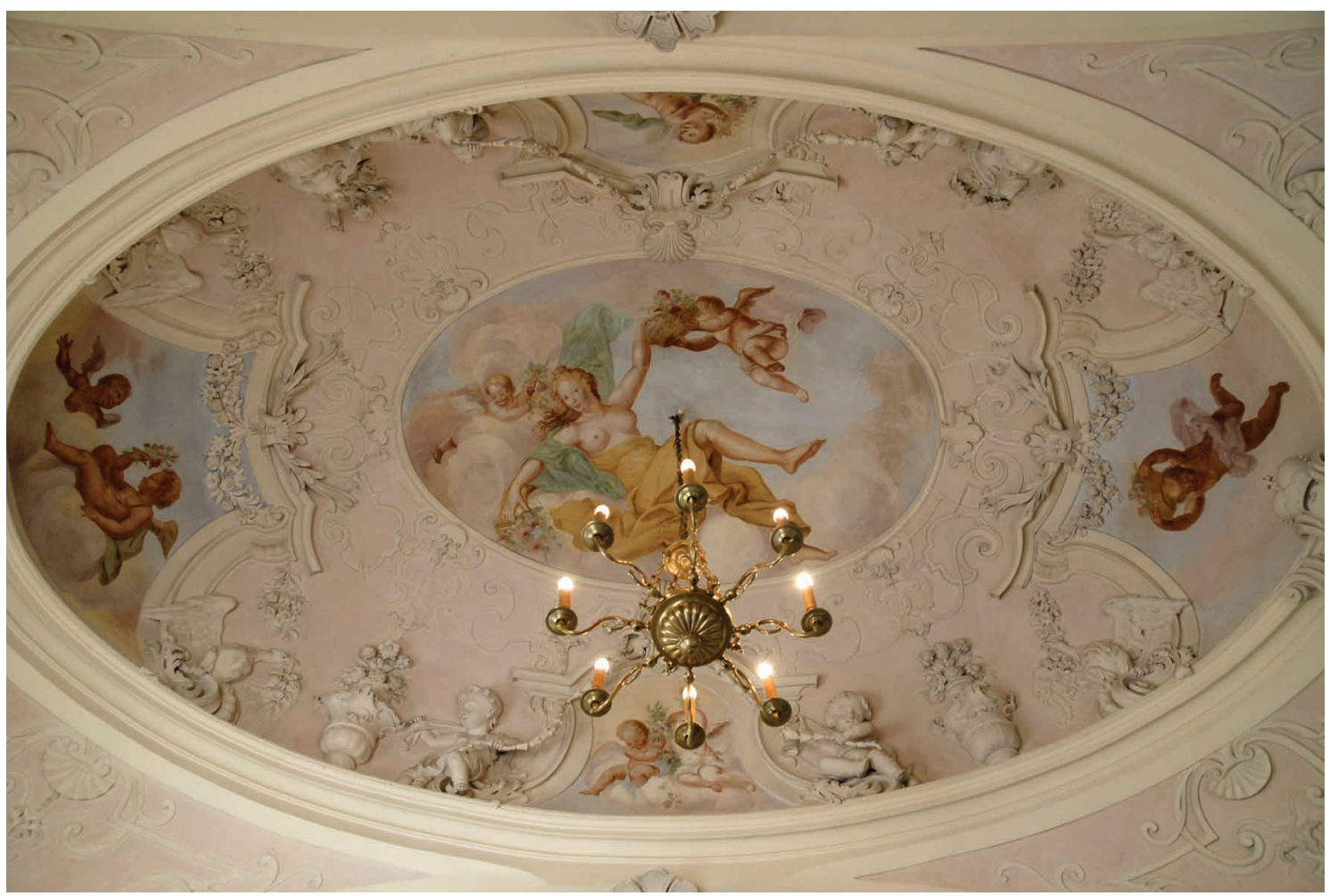

10. Giuseppe Rossi, fragment plafonu z wyobrażeniem Elżbiety Sieniawskiej jako Flory na sklepieniu sieni w skrzydle pólnocnym pałacu w Wilanowie, po 1725; dekoracja sztukatorska Francesco Fumo i Pietro Innocente Comparetti. Fot. Rafat Nestorow

tekta hetmanowej ${ }^{19}$. Pod nieobecność Spazzia prace nie przebiegały w należytym tempie, dlatego też burgrabia prosił o jego rychłe przybycie ${ }^{20}$.

Podczas licznych wyjazdów głównego projektanta, który doglądał równocześnie kilku ,fabryk", budowę prowadzono według jego wcześniejszych dyspozycji. W czasie nieobecności zastępował go jego zięć, sztukator Francesco Fumo ${ }^{21}$, dlatego też po śmierci Spazzia jego córka Francesca Fumo prosiła swoją mocodawczynię o niezwłoczne przysłanie z Łubnic do Wilanowa jej męża, który miałby czuwać nad dalszym przebiegiem robót ${ }^{22}$. W szczególnych sytuacjach, na przykład podczas wyjazdu sztukatora do Łubnic lub gdy prace wymagały większego doświadczenia, Spazzio zostawiał Fontanie odpowiednie dyspozycje ${ }^{23}$.

${ }^{19}$ BCzart., rkps 5980, 1. 46876, P. Więckowski do E. Sieniawskiej, 25 V 1723. Tego tygodnia pan Fontani stanq̨ tu w poniedziałek z mularzami którym ordinowawszy robotę odjechat do Warszawy, a Pan Spacy codziennie doziera tego wszystkiego.

${ }^{20}$ BCzart., rkps 5980, 1. 46932, P. Więckowski do E. Sieniawskiej, VII 1725: Rad bym serdecznie żeby JO Dobrodziejka przysłała jak najprędzej Pana Spazego, których on sam doziera [snycerzy - przyp. R.N.] we wszystkim, bo i roboty nie ida tak jak potrzeba.

${ }^{21}$ BCzart., rkps 5980, 1. 46937, P. Więckowski do E. Sieniawskiej, 10 I 1726: Pan Spazio w sobote przeszła stą pojechat do Sieniawy, ale nie odjechat, aż wszystko sporzadzit. Naprzód stolarzowi i szklarzowi kazal wziqć miarę na okna na sali wielkiej $i$ wszędy po pokojach, potem dispozytia dat p. Fumo żeby tego dozierat. Zob. też: NESTOROW, Pro domo et nomine suo..., s. 132.

${ }^{22}$ BCzart., rkps 5980, 1. 46952, P. Więckowski do E. Sieniawskiej, 31 VII 1726. Wspominał o tym również Mariusz KARPOWICZ, Artisti Ticinesi in Polonia nella prima metá del '700, Ticino 1999, s. 151, przypis 11; NESTOROW, „Tajemnicze okoliczności śmierci...”, passim.

${ }^{23}$ BCzart., rkps 5980, P. Więckowski do E. Sieniawskiej, 1. 46921, 8 III 1725: po odjeździe pana Spazego pan Fontany doglada wszystkich robotników, jak mularzow, jako i innych; 1. 46921, 8 III 1725: P. Fontany co był w Wilanowie 
Przedstawiony sposób organizacji prac wynikał, jak można przypuszczać, z faktu, że w Wilanowie działały niejako trzy ekipy artystyczno-budowlane: artyści i rzemieślnicy związani z dworem Sieniawskich (przede wszystkim członkowie warsztatu łubnickiego), „przedsiębiorstwo" budowlane Giuseppe Fontany oraz pojedynczy reprezentanci warszawskiego środowiska najmowani na krótkoterminowe kontrakty przez Spazzia lub Fontanę. Nominalnie wszyscy podlegali nadwornemu architektowi hetmanowej. Pewną swobodą cieszył się Fontana. Częste wyjazdy zarówno nadwornego architekta, jak i Fontany i Fuma powodowały, że nadzór nad ,fabryką” sprawowany był niejako rotacyjnie, przy czym ważkie dyspozycje wydawał jedynie Spazzio jako główny architekt hetmanowej.

Omawiając organizację wilanowskiej „fabryki” nie sposób pominąc zaangażowanych w skomplikowany proces budowy oficjalistów i zarządców dóbr Elżbiety Sieniawskiej oraz zależności pomiędzy nimi a architektem prowadzącym budowę.

Całym kompleksem dóbr wilanowskich zarządzał administrator (zwany czasem podstarościm). Sprawami finansowymi kierował pisarz prowentowy. Administratorowi podlegali: ekonom, ogrodnik oraz niższy personel. Siłą roboczą-pańszczyźnianą i najemną kierował ekonom (również grabarzami i chłopami zaciągniętymi do zwózki materiałów budowlanych). Jedne prace nadzorował pisarz prowentowy, inne administrator, co wiązało się z bezpośrednim ordynansem Sieniawskiej. Specjalne prerogatywy miał komisarz dóbr przysyłany do kontroli oficjalistów. Kierował on osobiście zleconymi pracami zarówno w rezydencji, jak i w ogrodzie, uzgadniał terminy ich wykonania, usprawniał administrowanie, dysponował także funduszami. Burgrabia współpracujący z administratorem i ekonomem podlegał bezpośrednio hetmanowej. Architekt współpracował z ekonomem i pisarzem prowentowym, którzy pomagali w dostarczeniu budulca, sporządzali, rejestry wydatków itp.; uczestniczył również w spisywaniu pałacowych inwentarzy ${ }^{24}$. Ponadto „fabryki” doglądał nierzadko zaufany przyjaciel Sieniawskiej, relacjonując jej przebieg prowadzonych prac, dorzucając własne spostrzeżenia i refleksje. W przypadku Wilanowa był nim blisko zaprzyjaźniony z Elżbietą Sieniawską Franciszek Bieliński ${ }^{25}$.

Administratorem dóbr wilanowskich w latach 1720-1723 był Stanisław Grochowski, który zajmował się głównie sprawami gospodarczymi i komasacją rozproszonych grun-

ogladat robote u snecerza, potem w ogrodzie byt i opatrzyt wszystko. Maja przyjechać tego tygodnia z cieślami do robienia rosztowania na sali, który mówił p. Spazio pisat do niego żeby to rosztowanie kazał zrobić, tym czasem niż on przyjedzie. BCzart., rkps 5809, G. Fontana do E. Sieniawskiej, 1. 10706, 26 VI 1725: Pan Spazzi już odjechat i zostawit mnie tu dozorca koło pałacu; 1.46861 (1 V 1724): W poniedziałek pan Fontany tu był u pana Spazego i zmówili sięo wszystkim.

${ }^{24}$ NOWAK, „Dobra wilanowskie...”, s. 58; NESTOROW, SITO, Rezydencja i dobra wilanowskie..., s. 9-10. Szczegółowe omówienie funkcjonowania warsztatu artystycznego Elżbiety Sieniawskiej zob. NESTOROW, Pro domo et nomine suo..., s. 130-141.

${ }^{25}$ NESTOROW, SITO, Rezydencja i dobra wilanowskie..., s. 10; NESTOROW, Pro domo et nomine suo..., s. 131; BCzart., rkps 5980, P. Więckowski do E. Sieniawskiej, 1. 46869, 25 III 1723: Jejmość pan cześnik tu rewidował wszystkie nadole i na górze plótna, którego poprawiane w ten dzień widziat i mówit, że pozłota niebardzo dobra; 1. 46872, 15 IV 1723: 11 dnia apr[ila] Jmć pan cześnik koronny obiadowat tu w karczmie $i$ widział tę banię która ma być na samym wierzchu i chwalit jej bardzo, że pozłota dobra się widzi; 1. 46883, 26 VIII 1723: Jmć pan cześnik byt tu w sobotę przeszła który się dobrze przypatrzył wszystkim robotom i bardzo wszystko chwalit tak rozumiem, że JO Dobrodziejka będzie kontenta co p. Spazio robi; 1. 46908, 7 IX 1724: JMość pan cześnik byt tu w Wilanowie który rewidowal sadzwkę i te kanały które kopia grabarze roskazywał p. Baraskiemu co potrzeba robić, ale p. Barański odpowiedziat, że JMość Dobrodziejka p. pisarzowi zleciła, tak Jmość p. cześnik kazła wołać p. pisarza ale go w domu nie było; 1. 46930, 26 VII 1725: w poniedziałek przeszty Jego Mość pan cześnik koronny byt tu w Wilanowie i chodził wszędy ogladajac wszystka robotę tak na pałacu jako też i pomarańczarnię widział i chwalit, że bardzo będzie pięknie jak tego wszystkiego dokończa, potym zaraz pojechat do Warszawy i nie popasat w Willanowie. 
tów ${ }^{26}$. Jako administrator odbierał ekspediowane do Wilanowa materiały budowalne oraz pieniądze. Dbał o stały napływ wykwalifikowanych robotników, przede wszystkim sprowadzanych z Rusi cieśli, których w zależności od potrzeb przydzielał do prac na folwarku i przy pałacu. Z racji swojej funkcji odpowiedzialny był za remont i utrzymanie budynków w odpowiednim stanie, zadbał o oszacowanie kosztów odbudowy, polecił pokryć pałac blachą, oszklić okna i uporządkować wnętrza. Jeździł do Warszawy w celu werbowania rzemieślników i pozyskania niezbędnych materiałów. Przez długi czas pertraktował z blacharzem królewskim w sprawie zatrudnienia go w Wilanowie, do czego ostatecznie nie doszło. Był obecny przy oględzinach pałacu przez Spazzia. Sprawując bezpośredni nadzór nad ogrodnikiem wilanowskim Johannem Georgiem Zeydlerem, jeździł z nim do pomarańczarni królewskiej w celu zobaczenia kształtu i wielkości tamtejszych waz i zrobienia na ich wzór waz do ogrodu wilanowskiego i Przybysławic. Dbał o odbudowę figarni, oszklenie inspektów. W swoich listach do Elżbiety Sieniawskiej relacjonował postęp prac budowlanych, prosząc o odpowiednie asygnacje na materiały budowlane, rzemieślników i funduszy niezbędnych do prowadzenia budowy ${ }^{27}$.

Stanisławowi Grochowskiemu podlegał ekonom wilanowski Andrzej Barański, pracujący od roku 1704 w dobrach Czerniaków, który po 1723 zastapił Grochowskiego i pozostał na stanowisku do końca roku 1725. Po nim nastąpił Świetlicki, którego zmienił w roku 1726 Paweł Głuchowski ${ }^{28}$. Rola Barańskiego była znacząca zarówno jako administratora, jak i doradcy hetmanowej. Zajmował się on również sprawami budowlanymi. Jeszcze jako administrator czerniakowski nadzorował konieczny remont tamtejszego pałacu i kościoła, który prowadzili zakontraktowani przez niego Francesco i Domenico Ceroni $^{29}$. Z pewnością jego sprawność i doświadczenie na placu budowy zostały zauważone przez Sieniawska. W Wilanowie, oprócz spraw gospodarczych polegających na przywróceniu finansowej płynności tamtejszym dobrom, zajmował się głównie odbudową zrujnowanych budynków gospodarczych. Jako ekonom kierował siłą roboczą zarówno pańszczyźnianą, jak i najemną. Tę ostatnią tworzyli cieśle masowo sprowadzani z dóbr ruskich hetmanowej (głównie z jarosławszczyzny i Kukizowa). Zajmował się zwózką

\footnotetext{
${ }^{26}$ NOWAK, „Dobra wilanowskie...”, s. 58-61; Dariusz BĄKOWSKI-KOIS, Zarzadcy dóbr Elżbiety Sieniawskiej studium historii mentalności 1704-1726, Kraków 2005, s. 36.

${ }^{27}$ NESTOROW, Pro domo et nomine suo..., s. 113, 129, 133-134; BCzart., rkps 5826, S. Grochowski do E. Sieniawskiej: 1. 13666 (13 II 1721); 1. 13667 (20 II 1721); 1.13668 (3 IV 1721); 1. 13669 (11 IV 1721); 1. 13671 (24 IV 1721); 1. 13672 (8 V 1721);1. 13672 (8 V 1721);1. 13673 (21 III 1721); 1.13674 (27 III 1721);1. 13675 (23 VI 1721); 1. 13677 (31 VII 1721); 1.13680 (11 IX 1721); 1. 13681 (15 IX 1721); 1. 13682 (19 IX 1721); 1. 13683 (16 X 1721); 1. 13684 (28 IX 1721); 1. 13685 (4 XII 1721); 1. 13686 (11 XII 1724); 1. 13687 (2 I 1722); 1.13688 (22 I 1722); 1. 13689 (25 I 1722); 1. 13690 (26 II 1722); 113691 (22 IV 1722); 1.13692 (7 V 1722); 113693 (20 V 1722); 1.13694 (10 VI 1722); 1.13696 (25 VI 1722); 1.13697 (2 VII 1722); 1. 13698 (23 VII 1722); 1. 13699 (1 X 1722); 1. 13700 (8 X 1722); 1. 13706 (4 II 1723); 1.13707 (11 II 1723); 1.13709 (4 III 1723); 1. 13713 (13 IV 1723); 1.13716 (6 V 1723); 1. 13717 (13 V 1723); 1. 13718 (20 V 1723); 1.13730 (27 VIII 1723); 1.13733 (27 VIII 1723).

${ }^{28}$ Bąkowski-Kois (Zarzadcy dóbr Elżbiety Sieniawskiej..., s. 36) uważa, że Barański był od początku głównym administratorem Wilanowa, a Grochowski jedynie pomocniczym. Informacje te stoją w sprzeczności z ustaleniami Nowaka (,Dobra wilanowskie...”, s. 56-58); NESTOROW, Pro domo et nomine suo..., s. 134-135.

${ }^{29}$ BOHDZIEWICZ, „Korespondencja artystyczna...”, s. 84-85, 265-266, 309; NESTOROW, „Sieniawscy w Warszawie...", s. 151-152; id., Pro domo et nomine suo..., s. 97, 119, 134; BCzart., rkps 5759, A. Barański do E. Sieniawskiej: 1. 542 (14 I 1704); 1. 549 (24 IV 1716); 1.550 (15 V 1711); 1. 554 (29 VII 1711); 1. 556 (17 XII 1711); 1.558 (24 VII 1712); 1. 559 (4 VIII 1712); 1. 566 (VIII 1719); 1.607 (14 I 1712); 1. 615 (19 X 1712); 1.631 (17 1713); 1.632 (14 IX 1713); 1. 634 (8 X 1713); 1. 643 (13 III 1714); 1. 652 (19 VII 1714); 1.657 (24 IV 1715); 1.658 (30 V 1715); 1.662 (8 X 1715); 1.683 (24 V 1714); 1. 685 (20 VI 1714); 1.686 (24 VI 1714); 1.691 (16 IX 1714); 1.692 (26 XI 1714); 1.693 (30 XI 1714); 1.694 (9 X 1717); 1. 697 (13 I 1718); 1.700 (3 III 1718); 1. 701 (30 III 1716); 1. 713 (27 IV 1719); 1.718 (8 VI 1719); 719 (6 VII 1719); 1.721 (20 VII 1719); 1.730 (2 V 1720).
} 
materiałów budowlanych. Miał duży udział w „fabryce” pałacowej, zawierając w imieniu hetmanowej kontrakty z artystami, m.in. ze złotnikiem warszawskim (Hupspan, Hupipan, Hypszenani) na pozłocenie bani na jednej z wież. W jego listach przewijają się echa zatargów ze Spazziem o robotników, którzy byli potrzebni zarówno architektowi, jak i Barańskiemu do prac na folwarkach ${ }^{30}$.

Administrator Świetlicki, podobnie jak poprzednik, dbał o odpowiednie zaopatrzenie „fabryki” w materiały budowlane, w szczególności drewno potrzebne na rusztowania i do sufitów. Sprowadzał też drewno lipowe dla rzeźbiarza Johanna Georga Plerscha, który przedkładał mu odpowiednie conotacye. W niezbędne drewno z lasów nieporęckich i dóbr zakrakowskich zaopatrywał również ogrodnika Johanna Georga Zeydlera ${ }^{31}$. Nadzorował prace prowadzone w ogrodzie, a ponadto był także zaangażowany w planowaną budowę cegielni na terenie dóbr wilanowskich, która miała stanąć pod Kabatami ${ }^{32}$.

Zakres kompetencji kolejnego administratora - Pawła Głuchowskiego, był zbliżony do poprzedników. Zaspokajał on finansowe pretensje Spazzia, nadzorował prace w pałacu, dbał o stały dopływ materiałów budowlanych. Po śmierci Sieniawskiej nadal pełnił funkcję administratora u Marii Zofii Denhoffowej, współpracując z burgrabią Piotrem Leonhardem, uczestnicząc $w$ pracach budowlanych prowadzonych pod kierunkiem Johanna Sigismunda Deybla ${ }^{33}$.

Pisarze prowentowi zajmowali się głównie wypłatami dla zatrudnionych na placu budowy wykonawców. Gotówkę pozyskiwali najczęściej z arendy (o czym przyjdzie jeszcze powiedzieć), ponadto w skład zapłaty wchodziła wydawana w naturze tzw. ordynaria. W latach 1723-1724 w Wilanowie na stanowisku pisarza prowentowego zatrudniony był Jędrzej Kopytkowski, którego w roku 1725 zastapił Michał Drygalski ${ }^{34}$. Zakres jego prerogatyw był szeroki i częściowo pokrywał się z obowiązkami ekonoma czy nawet zarządcy, co wiązało się z odpowiednimi decyzjami Sieniawskiej. Kopytkowski zajmował się głównie wypłatami dla Giuseppe Fontany i jego robotników, a także nadzorował cieśli przygotowujących drewno niezbędne do prac na folwarkach, w ogrodzie i pałacu. Na specjalne życzenie ściagał z Warszawy rzemieślników (ślusarza, szklarza i kominiarza) oraz artystów. Z polecenia hetmanowej odwiedzał Locciego w celu zatrudnienia w Wilanowie snycerza pracującego dawniej u Jana III, najprawdopodobniej Bartłomieja Michała Bernatowicza, który wykonać miał

\footnotetext{
${ }^{30}$ BCzart., rkps 5759, A. Barański do E. Sieniawskiej: 1.538 (31 II b.d.); 1. 539 (b.r.); 1.541 (11 VI b.d.); 1. 568 (24 V 1723); 1.569 (24 VI 1723); 1. 573 (23 III 1724); 1.574 (15 VI 1724); 1. 575 (6 VII 1724); 1. 577 (3 VIII 1724); 1. 578 , A. Barański do NN (17 VIII 1724); 1. 580 (20 VIII 1724); 1. 584 (1 III 1725); 1. 585 (8 III 1725); 1. 586 (14 V 1725); 1.590 (b.d.); 1.592 (b.d.); 1.593 (b.d.); 1.601 (11 II 1703); 1.734 (XI 1722); 1.736 (11 X 1722); 1. 738 (1 I 1723); 1.739 (1 I 1723); 1.740 (25 I 1723); 1.741 (28 I 1723); 1. 742 (4 II 1723); 1. 751 (22 IV 1723); 1.753 (16 VI 1723); 1.756 (15 VII 1723); 1.757 (22 VII 1723); 1.759 (9 VIII 1723); 1.768 (20 I 1724); 1. 769 (24 I 1724); 1.780 (1 VI 1724); 1.782 (14 VIII 1724); 1.786 (11 I 1725); 1. 787 (18 I 1725); 1. 789 (16 II 1725); 1.793 (26 IV 1725); 1.794 (22 VII 1725).

${ }^{31}$ NESTOROW, Pro domo et nomine suo..., s. 134-135.

32 Projekt owej budowli przygotował specjalnie sprowadzony specjalista w tej dziedzinie, niejaki „de Bleur”. Koszt samego drewna na budowę Świetlicki szacował na 1300 talarów. Sprowadzono strycharza z Torunia, który pomimo usilnych poszukiwań nie mógł znaleźć w okolicach Wilanowa odpowiedniej gliny, co pod znakiem zapytania stawiało sens budowy kosztownej cegielni. BCzart., rkps 5957, W. Świetlicki do E. Sieniawskiej: 1. 40838 (b.d.); 1.40840 (3 I 1726); 1. 40841 (10 I 1726); 1.40842 (14 I 1726); 1.40843 (24 I 1726); 1. 40844 (31 I 1726); 1.40845 (1 II 1726); 1. 40846 (25 II 1726); 1. 40846 (14 III 1726). Zob. też: NESTOROW, SITO, Rezydencja i dobra wilanowskie..., s. 11, 13.

${ }^{33}$ BCzart., rkps 5817, P. Głuchowski do E. Sieniawskiej: 1.1207 (9 I 1726); 12095 (7 VII 1726); P. Głuchowski do M.Z. Denhoffowej: 1. 12105 (1 XII 1729); 1. 12106 (8 XII 1729); 1. 12107 (15 IX 1729); 1. 12108 (22 XII 1729); 1. 12109 (30 I 1729); 1.1210 (19 I 1730).

${ }^{34}$ NOWAK, „Dobra wilanowskie...”, s. 70; NESTOROW, Pro domo et nomine suo..., s. 135.
} 
rzeźbę Bachusa do ogrodu ${ }^{35}$. Kopytkowski nadzorował część prac przy remoncie oficyn i pałacu, a przede wszystkim w ogrodzie, kupował również cegłę i wapno ${ }^{36}$.

Obowiązki Michała Drygalskiego wydają się znacznie ograniczone w porównaniu z jego poprzednikiem. Oprócz zwyczajowych opłat dla rzemieślników, w tym Giovanniego Spazzia, zajmował się dostarczeniem odpowiednej ilości i gatunku drewna dla Johanna Georga Plerscha. Zapewniał mu pieniądze, które niechętnie wypłacał arendarz wilanowski Abraham Zelmanowicz ${ }^{37}$.

Podstarości wilanowski Franciszek Stawski nadzorował wyrąb drzew na budowę, a także miał jakiś udział w sprawach personalnych. Osobiście zają się dwoma ogrodniczkami przysłanymi z Międzyrzeca Podlaskiego do pomocy ogrodnikowi Johannowi Georgowi Zeydlerowi ${ }^{38}$. Podobną rolę pełnił w Nieporęcie nieznany z imienia Gucy, odpowiedzialny za transport drewna oraz gontów do Wilanowa, a w miarę intensyfikacji prac również siły pociagowej $^{39}$.

Kontrolę nad sprawnym działaniem administracji lokalnej, w tym również nad przebiegiem prac budowlanych, sprawowali przysyłani w ślad za administratorami poszczególnych majątków lustratorzy. W Wilanowie byli to Podłużewicz, Józef Łukszyński (obydwaj wcześniej działający na terenie dóbr ruskich), Turbiński i Andrzej Górski. Relacjonowali oni skrupulatnie swojej chlebodawczyni przebieg prac budowlanych, partycypowali w sprawach finansowych, rozporządzając wypłatami dla artystów i rzemieślników, uczestniczyli w spisywaniu pałacowych inwentarzy ${ }^{40}$.

Nie można też pominąc istotnych z punktu widzenia spraw organizacyjnych inwentarzy gospodarczych, w których osobną pozycję stanowił skrupulatny opis rezydencji, a w szczególności stanu jej zachowania. W ten sposób Sieniawska otrzymywała informację dotyczącą stanu budowli i niezbędnych napraw. Podstawowym powodem spisywania inwentarza gospodarczego była konieczność oceny finansowych możliwości poszczególnych kluczy gospodarczych, czyli de facto wysokości wpływów intraty do pańskiego skarbu, a także wydajności i rzetelności lokalnego aparatu administracyjnego ${ }^{41}$.

W systemie gospodarczym dóbr Sieniawskich źródłem ,żywej gotówki” był arendarz, bezpośrednio obciążony bieżącymi wydatkami związanymi z wypłacaniem pensji

\footnotetext{
${ }^{35}$ NESTOROW, ,,Wilanowski epizod...”, s. 73.

${ }^{36}$ BCzart., rkps 5858, J. Kopytkowski do E. Sieniawskiej: 1.19307 (17 II 1724); 1. 19313 (30 III 1724); 1.19314 (20 IV 1724); 1. 19316 (4 V 1724); 1. 19317 (11 V 1724); 1.19318 (18 V 1724); 1. 19323 (13 VI 1724); 1. 19324 (6 VII 1724); 1. 19326 (13 VI 1724); 1.19327 (20 VI 1724); 1. 19328 (3 VIII 1724); 1. 19329 (10 VIII 1724); 1. 19331 (24 VIII 1724); 1. 19336 (20 IX 1724); 1.19337 (5 X 1724).

${ }^{37}$ BCzart., rkps 5801, M. Drygalski do E. Sieniawskiej: 1.9299 (22 II 1725); 1.9301 (8 III 1725); 1.9305 (26 IV 1725); 1. 9306 (16 V 1725); 1. 9313 (2 VIII 1725).

${ }^{38}$ BCzart., rkps 5995, F. Stawski do E. Sieniawskiej: 1. 40185 (30 I 1724); 1.40186 (6 III 1721).

${ }^{39}$ NESTOROW, Pro domo et nomine suo..., s. 136; BCzart., rkps 5828, Gucy do E. Sieniawskiej: 1. 19351 (b.d.); 1. 19334 (b.d.); 1. 13956 (30 III b.r.); 1313969 (23 I 1721); 1. 19370 (30 I 1721); 1. 19371 (6 II 1721); 1. 13972 (13 II 1721); 1. 13975 (13 III 1721); 1. 13976 (19 III 1721); 1. 13996 (17 VI 1722); 1. 13997 (25 VI 1722); 1. 14000 (22 VII 1722); 1. 14001 (22 VIII 1722); 1. 14003 (28 I 1723); 1. 14004 (4 VII 1723); 1. 14005 (11 VII 1723); 1. 14007 (11 III 1723); 1.14008 (31 III 1723).

${ }^{40}$ NOWAK, „Dobra wilanowskie...”, s. 66; NESTOROW, Pro domo et nomine suo..., s. 136. Znaczna cześć liczacej przeszło 400 listów korespondencji Józefa Łukszyńskiego została ostatnio opublikowana; zob. Korespondencja Elżbiety z Lubomirskich Sieniawskiej, kasztelanowej krakowskiej, t. II: Jaśnie Oświecona Mościa Księżno Dobrodziejko. Informatorzy i urzędnicy, oprac. Bożena POPIOŁEK, Urszula KICIŃSKA, Agnieszka SŁABY, Warszawa-Bellerivesur-Allier 2016, s. 104-249 (Monumenta Poloniae Epistolaria).

${ }^{41}$ Janusz NOWAK, „Dobra i zamek w Spytkowicach za czasów Sieniawskich i Czartoryskich (1704-1782)”, Krakowski Rocznik Archiwalny, 2009, t. 14, s. 100.
} 
kwartalnych, zaliczek i solariów artystom i rzemieślnikom. Wypłaty uwarunkowane były bezpośrednimi „ordynansami” Sieniawskiej lub pośrednimi przekazywanymi na ręce zarządców lustratorów czy gubernatorów. System ten powodował szybkie wyczerpanie finansowych możliwości arendarza, co z kolei znacznie opóźniało wypłaty. Z tego powodu sprawy dotyczące finansów zajmują znaczną część kierowanych do hetmanowej listów, a kiedy te okazywały się niewystarczające także próśb w formie pisemnych suplik. Pisali je zarówno artyści (Pietro Innocente Comparetii) i oficjaliści (S. Grochowski) skarżąc się na niewypłacone „kwartały”, jak również arendarz Abraham Zelmanowicz bolejąc nad nadmiernymi jego zdaniem obciążeniami finansowymi, którym nie mógł sprostaćc ${ }^{42}$.

Sprawna organizacja placu budowy skomplikowała się po śmierci Giovanniego Spazzia 29 lipca 1726 r. ${ }^{43}$ Zbieg okoliczności sprawił, że zgon nastapił dokładnie w dniu odbywającego się w rodowych Brzeżanach pogrzebu męża Elżbiety z Lubomirskich, hetmana Adama Mikołaja Sieniawskiego (zm. 18 lutego 1726 r. we Lwowie) ${ }^{44}$. Nagłe odejście Spazzia wywołało popłoch u burgrabiego pałacowego Piotra Więckowskiego, który niezwłocznie po poinformowaniu Sieniawskiej o tym smutnym wydarzeniu prosił o wydanie nowych dyspozycji odnośnie do dalszych prac remontowo-budowlanych przy pałacu. Do czasu ich wydania kontrolę nad przebiegiem oraz nadzór nad artystami i rzemieślnikami przejął Giuseppe Fontana, który zajął się też przygotowaniami do pogrzebu Spazzia ${ }^{45}$. Trudnym zadaniem dla warszawskiego architekta było z pewnością zatrzymanie zatrudnionych na krótkotrwałych umowach i kontraktach artystów, a także pomniejszych rzemieślników, którzy w zaistniałej sytuacji obawiali się o swój los. Ciekawie przedstawiała się sprawa dalszego opłacania podległych Spazziemu ludzi. Obowiązek ten po jego śmierci przypadł córce Francesce, żonie sztukatora Francesca Fuma ${ }^{46}$. Pogrążona w smutku po stracie ojca nie była w stanie wywiązywać się należycie z przypadłych jej zleceń, w związku z tym prosiła Sieniawską o jak najszybsze przysłanie z Łubnic jej męża ${ }^{47}$.

Do czasu wydania przez Sieniawską nowych rozporządzeń prace kontynuowano pod nadzorem Giuseppe Fontany wedle ostatnich dyspozycji Spazzia. Francesca Fumo wypłacała nadal artystom i rzemieślnikom ordynowane przez ojca sumy, starając się tym samym

\footnotetext{
${ }^{42}$ NESTOROW, SITO, Rezydencja i dobra wilanowskie..., s. 12-13 (tamże opublikowany bogaty materiał źródłowy); NESTOROW, Pro domo et nomine suo..., s. 142-144.

${ }^{43}$ NESTOROW, „Tajemnicze okoliczności śmierci...”, passim.

${ }^{44}$ Rafał NESTOROW, „Magna pompa et splendido aparatu. Ceremonia pogrzebowa hetmana Adama Mikołaja Sieniawskiego we Lwowie i Brzeżanach w r. 1726", [w:] Sztuka kresów wschodnich, t. 6, Kraków 2006, s. 225-239.

${ }^{45}$ NESTOROW, „Tajemnicze okoliczności śmierci...”, s. 511-512; BCzart., rkps 5980, 1. 46952, 31 VII 1726: Pan

Fontany tym czasem dyspozyciey JO Dobrodziejki czynni wszystko co może tak w robotach jak też $i$ w tym pogrzebie dispozytia wszystka czyni do dyspozyciey JO Dobrodziejki i ludzi zatrzymuje przy tychże robotach co maja robić.

${ }^{46}$ BCzart., rkps 5890, 1. 46959, P. Więckowski do E. Sieniawskiej, Wilanów 5 IX 1726: Pani Fumo obiecała i obligowała się czynić wszystko do przyjazdu JO Dobrodziejki. Robota ta co ludzie robia naznaczona od nieboszczka pana Spazego jest tacna $i$ widoma tylko kontynuować.

${ }^{47}$ BCzart., rkps 5890, 1. 46952, P. Więckowski do E. Sieniawskiej, Wilanów 31 VII 1726: Pieniadze pani Fumo jeszcze swoje daje. Pani Fumo sztukatorowa ściska za nóżki JO Dobrodziejke, a uprasza aby JO Dobrodziejka miała się w swojej łasce zachowanej i chciała męża jej jak najprędzey przystać do dysponowania wszystkich rzeczy; BCzart., rkps 5890, 1. 46954, P. Więckowski do E. Sieniawskiej, Wilanów 14 VIII 1726: Pani Fumo sztukatorowa ściska za nóżki JOć Dobrodziejkę a uprasza aby łaskwa była na niq, a chciała jej męża przystac bo sama sobie rady nie może dać i nie miała żadnej wiadomości o nim i razu niepisat do niej, która bardzo się turbuje o to. NESTOROW, SITO, Rezydencja i dobra wilanowskie..., s. 10. NESTOROW, Pro domo et nomine suo..., s. 132. O opłacaniu artystów przez Franceskę Fumo zob. Mariusz KARPOWICZ, „Stiukatorzy wilanowscy XVIII wieku: Francesco Fumo i Pietro Innocente Comparetti”, Barok. Historia-Literatura-Sztuka, 1998, t. VI/1, s. 151, przyp. 11.
} 
wespół z przybyłym z Łubnic mężem utrzymać stały skład warsztatu budowlanego ${ }^{48}$. Więckowski trzykrotnie (ostatni raz 14 sierpnia) dopytywał się Sieniawskiej o dalsze dyspozycje, a zwłaszcza o to, kto ma być odpowiedzialny za losy „fabryki” pałacowej ${ }^{49}$. Taki sposób zarządzania pracami budowlanymi musiał się sprawdzić, ponieważ Sieniawska nie wydała innych rozporządzeń, a Giuseppe Fontana objął główne stanowisko w „,fabryce” wilanowskiej ${ }^{50}$. Śmierć Spazzia przyczyniła się do niewątpliwego choć krótkotrwałego sukcesu Giuseppe Fontany. Warto również sprecyzować bliżej zakres obowiązków Fontany, uważanego powszechnie za architekta-konduktora prowadzącego w Wilanowie prace budowlane według projektów Spazzia. Fontana został zatrudniony do Wilanowa zwłaszcza w celu oszacowania zniszczeń i przygotowania kosztorysu prac remontowych, o czym sam wspomina w jednym z listów do Sieniawskiej: ,[...] a ja na usługach Waszey Xny Jmci dozorcą i do sporządzenia tej reparacyi obliguję się jeśli zajdzie roskaz do Waszey Xny Jmci [...]"51. Kolejnym zadaniem Fontany było wybudowanie pomarańczarni, o której w superlatywach pisał ogrodnik Johann Georg Zeydler ${ }^{52}$. Również Fontana informował o wspaniałości wznoszonej budowli ${ }^{53}$. Osobnym kontraktem architekt warszawski był związany wybudować kościół w nieodległym Powsinku ${ }^{54}$.

Śmierć Spazzia stała się przyczyną wielu kłopotów organizacyjnych w sprawnym funkcjonowaniu ,fabryki” wilanowskiej. Brak nadwornego architekta spowodował dezorganizację, korzystali z niej związani kontraktami artyści i rzemieślnicy, opuszczając Wilanów i przyjmując inne zlecenia. Postępowali tak nie tylko artyści związani krótkotrwałymi

\footnotetext{
${ }^{48}$ BCzart., rkps 5890, 1. 46959, P. Więckowski do E. Sieniawskiej, Wilanów 2 X 1726: Pisaliśmy z panem Fumo dwa razy do Pana Ferdynanda [Heindla].

49 BCzart., rkps 5890, 1. 46952, P. Więckowski do E. Sieniawskiej, Wilanów 31 VII 1726: Roboty naznaczone od nieboszczyka jeszcze ida jak należy; 1. 46953 (Wilanów 7 VIII 1726): Po drugi raz oznajmuję a to dla ordinansu Jej Mości Dobrodziejki kto fabrika pałacowa będzie zawiadowat. Dotychczas pani Fumo daje pieniadze na fabrike, a Pan Fontany ordynuje i continuuje jak pan Spazio zaczat i wszystkie roboty ida dobrze; 1. 46954 (Wilanów 14 VIII 1726): Już to trzecia poczte piszę do JO Dobrodziejki do wiadomości o śmierci JMości pana Spazego, że już dwie niedzile $w$ ponidziałek minat jak umart, a nie mamy żadnej wiadomości ni ordynansu co ma czynić p. Fumo z temi ludzmi co robiq w pałacu, perswadujemy aby zatrzymywała poty poki ordynans pański tu nie przydzie ona ledwie się nie rozpuknie od płaczu jednak że wedlug ordinansu robot p. Spazego wypłaca im co tydzień i robia to co im niebiszczyk byt rozkazat. ${ }^{50}$ BOHDZIEWICZ, „Korespondencja artystyczna...”, s. 167; NESTOROW, SITO, Rezydencja i dobra wilanowskie..., s. 11.

${ }^{51}$ BCzart., rkps 5809, 1. 10702, G. Fontana do E. Sieniawskiej, 5 IX 1720.

52 BCzart., rkps 5776, 1. 4749, J. G. Zeydler do E. Sieniawskiej, 14 V 1725: Donoszę Jaśnie O Pani, iż p. Fontanna swoja zaczą z fundamentu wyprowadzać pomarańczarnię, a dnia wczorajszego Jmć p. Szpadz wynalazł takq inwencję pomarańczarni, że ani $w$ Polszcze, ani te $w$ Saxonii jeszcze nie widziałem, z czego ja wielce kontent, że tak ma być obserwowana, że ani ogień, ani insze incydendia zaszkodzić [jej] nie moga, [z] której jak rozumiem, że JOWM Pani Dobrodziejka wielce także kontenta.

${ }^{53}$ BCzart., rkps 5809, 1. 10690, G. Fontana do E. Sieniawskiej, b.d.: W strukturze pomarańczarni będę się jak najlepiej akomodowat i nie tylko królewskiej, lecz i w całej Polsze edyfikacyi takowej nie wynajdzie jako inwencyiq muruję, gdyż $i$ wewnatrz, chociaż moje krzywdy będzie, przecie ksztattniejszej od królewskiej uczynię kondekorację. Powyższy cytat oraz cytat w przypisie 52. nie dają jasnej odpowiedzi na pytanie, kto zaprojektował wilanowską pomarańczarnię. Być może projekt wyszedł spod ręki Spazzia, a Fontnana wprowadził do niego jakieś modyfikacje (mógł też zmienić projekt po śmierci Spazzia w 1726 r.). Niewykluczone również, że mamy do czynienia z sytuacjąjak w przypadku warszawskiego pałacu Sieniawskich, gdzie projekty Baya poprawiał Agostino Locci i nadzorujący prace budowlane z ramienia hetmana A.M. Sieniawskiego Jan Baptysta Dessieur. Można zatem uznać, ze pomarańczarnia jest dziełem zarówno Spazzia, jak i prowadzącego budowę Fontany; por. NESTOROW, „Jan Baptysta Dessieur...”, s. 351; id., Pro domo et nomine suo..., s. 70-74.

${ }^{54}$ BOHDZIEWICZ, „Korespodencja artystyczna...”, s. 77-78, 80-81; NOWAK, „Dobra wilanowskie...”, s. 81-82; NESTOROW, SITO, Rezydencja i dobra wilanowskie..., s. 12; WYSZOMIRSKA, „Fontana (Fontanna, Fontani) Giuseppe...", s. 133.
} 
kontraktami, jak np. Johann Georg Plersch ${ }^{55}$, lecz także artyści ,jurgieltowi”, którzy zobowiązani kontraktem mogli podejmować zlecenia u innych jedynie po uprzednim wyrażeniu zgody przez mocodawcę. Takiej zgody nie miał Pietro Innocente Comparetti podejmując prace u warszawskich teatynów, co wywołało gniew Sieniawskiej ${ }^{56}$. Niezadowolenie hetmanowej wywoływały też wyjazdy Giuseppe Fontany, z których musiał się dokładnie tłumaczyć, bojąc się utraty łask wpływowej magnatki. O zaniedbywanie budowy wilanowskiej oranżerii oskarżał go bowiem ogrodnik Johann Georg Zeidler ${ }^{57}$.

Kluczowym momentem w dziejach ,fabryki” pałacowej, zamykającym de facto ważny etap $\mathrm{w}$ dziejach budowy wilanowskiego zespołu rezydencjonalnego była $\mathrm{z}$ pewnością śmierć Giovanniego Spazzia ${ }^{58}$. Do tego czasu prace prowadzono ściśle według jego zaleceń, a w szerszej perspektywie kontynuowano dzieło Jana III. Kolejny etap rozpoczął się w roku 1727, kiedy Elżbieta Sieniawska zatrudniła Johanna Sigismunda Deybla ${ }^{59}$, którego prace za czasów Marii Zofii Czartoryskiej primo voto Denhoffowej, wyznaczają zupełne nowy, odmienny okres w historii artystycznych dziejów wilanowskiej rezydencji.

\footnotetext{
55 NESTOROW, „Wilanowski epizod...”, s. 119; BCzart., rkps 5890, 1. 46954, P. Więckowski do E. Sieniawskiej, Wilanów 14 VIII 1726: Snecerz nic nie robi w pałacu tylko teraz najczęściej w Warszawie i mówi, że już nie będzie robił. P. Spazyo do śmierci się gniewał na niego i nie chciał mu gadać ni spojrzeć na niego umierajac, że nie skonczyt tego co mu ordinowat.

${ }^{56}$ BCzart., rkps 5890, 1.46958, P. Więckowski do E. Sieniawskiej, 14 VIII 1726: Wedtug roskazu JO Dobrodziejki nie mogę dać responsu tego tydnia. Pan Comaparety gdzie się obraca już kilka niedziel alem go nie widziat prawda, że pan Fontany byt tu $w$ Wilanowie $w$ Niedzielę u Pani Fumo i powiedat, że się widziat z nim u teatynów, że tam ma robić więc ja się tam w ten tydzień obaczę z nim i będę mu mówił aby się nie ważyt ni kędy robić przez rozkaz JO Dobrodziejki, w niedziele przeszła Pan Fumo odjechał do Eubnic po swoje kwartały. NESTOROW, „Sieniawscy w Warszawie...”, s. 154. Zleceń w Warszawie podejmował się też współpracujący z nim Francesco Fumo, aczkolwiek tym razem już za pozwoleniem E. Sieniawskiej. W 1728 r. czynny był przy dekoracji pałacu Błękitnego, przypisuje mu się ponadto nagrobek Jerzego Dominika Lubomirskiego z kościoła św. Anny oraz dekorację pałacu Przebendowskich; zob. Anna SARATOWICZ, Pałac Przebendowskich, Warszawa 1990, s. 40-41; KARPOWICZ, „Stiukatorzy wilanowscy...”, s. $158-159$.

${ }^{57}$ BCzart., rkps 5809, 1. 101714, G. Fontana do E. Sieniawskiej, 18 VII 1726: Jako się dawniejszymi asekurował listami tak i teraz nie innq WXMśsi wyrażam asekuracja wszelka i do dodania to tylko jest ogrodnika, iz tak niestusznie na mnie przed WXMścia inwektywę wyrazil żem miat nie dogladać tej roboty to prawda żem byt odjechat na krótki czas do Xiążęcia Jaśnie Czartoryskiego alem takiego majstra zostawit, który na tym znający się dobrze, należycie doglądat, tegoż samego który świętej pamięci JW. Jm Pan WXMści nieboszczyka pałac murował dlategom o jego dozorze niewatpit, powtóre, iż zjechwszy kilka razy do Wilanowa dozoru nie czyniłem bom musiał w pałacu, dyspozycji pana Spazzia nieboszczyka prosequować do którego dnia dzisiejszego kompetencję czynię tak wiele pomocników zabrałem z Warszawy abym mógt uczynić pozostałej roboty satysfakcję, którq WXMść za przyjazdem obaczywszy niewatpię, iż moja praca nadaremna nie będzie.

${ }^{58}$ NESTOROW, ,,Tajemnicze okoliczności śmierci...”, s. 511-512. Na temat losów artystycznego warsztatu po śmierci hetmanowej zob. NESTOROW, Pro domo et nomine suo..., s. 140-141.

${ }^{59}$ NESTOROW, „Spazzio (Spazio, Spacy, Spatz) Giovanni...”, s. 447; id., Pro domo et nomine suo..., s. 103, 107, 132, 135, 137, 215, 247, 272, 322; Jakub SITO, „Deybel (Teubel, Teuble, Teubler, Deibler) Johann Sigmund (Jan Zygmunt) von Hammerau", [w:] Stownik architektów i budowniczych środowiska warszawskiego..., s. 117.
} 


\section{The Wilanów Palace Fabrica under Elżbieta Sieniawska. Remarks on the Organization of a Magnate Construction Site in the $18^{\text {th }}$ Century Polish-Lithuanian Commonwelth}

One of the more interesting periods in the history of the Wilanów Palace spanned 1720-29 when the former residence of King Joh III Sobieski residence in the suburbs of Warsaw was owned by Elżbieta Sieniawska née Lubomirski, wife of the Grand Hetman of the Crown and Cracow Castellan. Interestingly, the resourceful magnate competed for the Palace against King Augustus II and she won the rivalry. At the point when Sieniawska acquired the key to the Wilanów Palace, it was in a deplorable state, while the ruined home farms did not yield expected income. In view of this Sieniawska decided to restore the financial liquidity to the estates there, which would allow to e.g. maintain the Palace. Elżbieta Sieniawska née Lubormiski was one of the major figures on the political and artistic arena of the Saxon era.

In her founding activity, Sieniawska clearly followed the Ciceronian principle: publicam magnificentiam diligit. Rich painting and sculptural decoration was a kind of a symbolical 'costume', and was perceived as such by the contemporary. A special role in consolidating the image of the powerful magnate was played by the Wilanów Palace she bought on 3 July 1720 . This deal crowned the gradual purchase of the royal estates that Sieniawska took care of following the departure of Marie Casimire for Rome (she owned e.g. the Wysocko and Surochów Palaces and the Tarnopol estates). Not only did Sieniawska renovate the run down Palace, but she also completed both lateral wings, additionally subtly interlacing her own family motif with the complex ideological programme of the residence of the 'Polish Hercules'. The Wilanów Palace turned into a fashionable venue, frequently visited by leading magnates, including Augustus II himself.

Such a serious undertaking that the renovation and extension of the former royal residence implied required not only the involvement of an array of artists and craftsmen, but also clerks responsible for the supply of building materials, for paying the workers, and for the operating of the whole fabrica, namely the building workshop. The core of the team conducting the artistic and construction works on the Wilanów residence were the artists and craftsmen employed by Sieniawska at Łubnice, where she had her main residence modernized. They did not form any internal structure within the magnate's court, but a hierarchized group of specialists reporting to Sieniawska's architect Giovanni Spazzio who served not merely as the main designer, but also as the supervisor of all the artistic undertakings. As can be clearly seen in the sources, the workshop was not excessively numerous. Since its core was composed of several specialists, Sieniawska was obliged to resort to hired contractors. The leading role in this respect was played by the Warsaw circles represented e.g. by members of the Ceroni family; Giuseppe Fontana, a building contractor; Johann Georg Plersch, a sculptor; or Giuseppe Rossi, a painter, to name merely the major ones. Through the analysis of the preserved sources, the operations of that team of permanent and temporarily employed contractors could be precisely reconstructed, as could be the organization of the Palace fabrica. Its effective operating did not only depend on the artists, but also on the plenipotentiaries associated with land administration. A particular role of Burgrave, previously marginalized, was emphasized. Even less is known of other land clerks involved in the fabrica (administrators, deputy starosts, administrators, governors, etc.). It was equally interesting to follow the financing of the works, the process of remunerating the artists. As was found, the role of particular importance was attributed to a local publican who had cash and appropriately paid it out against a written request. 
